\title{
Partitioning behavior of trace elements between dacitic melt and plagioclase, orthopyroxene, and clinopyroxene based on laser ablation ICPMS analysis of silicate melt inclusions
}

\author{
Matthew J. Severs ${ }^{\mathrm{a}, \mathrm{d}}$, James S. Beard ${ }^{\mathrm{b}}$, Luca Fedele ${ }^{\mathrm{a}}$, John M. Hanchar ${ }^{\mathrm{c}}$, \\ Scott R. Mutchler ${ }^{\mathrm{a}}$, Robert J. Bodnar ${ }^{\mathrm{a}, *}$ \\ ${ }^{a}$ Fluids Research Laboratory, Department of Geosciences, Virginia Polytechnic Institute and State University, Blacksburg, VA 24061, USA \\ ${ }^{\mathrm{b}}$ Virginia Museum of Natural History, Martinsville, VA 24412, USA \\ ${ }^{\mathrm{c}}$ Department of Earth Sciences, Memorial University of Newfoundland, St. John's, Nfld, Canada A1B 3 X5 \\ ${ }^{d}$ Department of Geological Sciences, Ohio University, Athens, OH 45701, USA
}

Received 30 September 2008; accepted in revised form 12 January 2009; available online 22 January 2009

\begin{abstract}
Partitioning behavior of Sc, Ti, V, Mn, Sr, Y, Zr, Nb, Ba, La, Nd, Sm, Eu, Gd, Dy, Ho, Yb, Hf, and Pb between dacitic silicate melt and clinopyroxene, orthopyroxene, and plagioclase has been determined based on laser ablation-inductively coupled plasma mass spectrometric (LA-ICPMS) analysis of melt inclusions and the immediately adjacent host mineral. Samples from the 1988 eruption of White Island, New Zealand were selected because petrographic evidence suggests that all three mineral phases are in equilibrium with each other and with the melt inclusions. All three phenocryst types are found as mineral inclusions within each of the other phases, and mineral inclusions often coexist with melt inclusions in growth-zone assemblages. Compositions of melt inclusions do not vary between the different host minerals, suggesting that boundary layer processes did not affect compositions of melt inclusions and that post-trapping modifications have not occurred.

Partition coefficients were calculated from the host and melt inclusion compositions and results were compared to published values. All trace elements examined in this study except $\mathrm{Sr}$ are incompatible in plagioclase, and all measured trace elements except for $\mathrm{Mn}$ are incompatible in orthopyroxene. In clinopyroxene, Sc, V, and Mn are compatible, and Y, Ti, HREE, and the MREE are only slightly incompatible. Most partition coefficients overlap the wide range of values reported in the literature, but the White Island data are consistently at the lower end of the range in published values. Results from the literature obtained using modern microanalytical techniques such as secondary ion mass spectrometry (SIMS) or proton induced X-ray emission spectroscopy (PIXE) also fall at the lower end of the published values, whereas partition coefficients determined from bulk analysis of glass and crystals separated from volcanic rocks typically extend to higher values. Rapid crystal growth-rates, crystal zonation, or the presence of accessory mineral inclusions in phenocrysts likely accounts for the wide range and generally higher partition coefficients obtained using bulk sampling techniques. The results for $3+$ cations from this study are consistent with theoretical predictions based on a lattice strain model for site occupancy. The results also confirm that the melt inclusion-mineral (MIM) technique is a reliable method for determining partition coefficients, as long as the melt inclusions have not experienced post-entrapment reequilibration.
\end{abstract}

(C) 2009 Elsevier Ltd. All rights reserved.

\footnotetext{
* Corresponding author. Fax: +1 5402313386.

E-mail address: rjb@vt.edu (R.J. Bodnar).
}

\section{INTRODUCTION}

During the generation and crystallization of silicate melts, most elements are distributed unevenly between the melt phase and the crystallizing minerals (Shaw, 2006). 
The partition coefficient describes the distribution of an element between a mineral and melt. For an element $i$, the Nernst partition coefficient $D_{i}$, is defined as

$D_{i}^{\text {mineral } / \text { melt }}=C_{i}^{\text {Mineral }} / C_{i}^{\text {Melt }}$

where $D_{i}$ is the partition coefficient for element $i$, and $C_{i}^{\text {Mineral }}$ and $C_{i}^{\text {Melt }}$ are the concentrations of element $i$ in the crystal (mineral) and in the melt from which the mineral is precipitating, respectively (Beattie et al., 1993). Reliable values for partition coefficients for a wide range of minerals and silicate melt compositions are necessary to understand and model igneous processes such as crystal fractionation, partial melting, and assimilation (e.g., Gast, 1968; Zielinski and Frey, 1970; Pearce and Cann, 1973; Rollinson, 1993; Wilson, 1994; Shaw, 2006). Trace elements that exhibit a wide variation in geochemical behavior and have a wide range of abundances in natural samples, including largeion lithophile elements (LILE), high-field strength elements (HFSE), and rare earth elements (REE), are especially useful to understand and constrain these igneous processes (Rollinson, 1993; Wilson, 1994; Shaw, 2006).

An early method used to determine the distribution of trace elements between melt and minerals involved analysis of phenocrysts and the surrounding glassy matrix of extrusive volcanic rocks. Such studies include the pioneering work of Onuma et al. (1968), Schnetzler and Philpotts (1970), Hart and Brooks (1974), and continue to more recent studies by Irving and Frey (1984), Ewart and Griffin (1994), Thompson and Malpas (2000), and Norman et al. (2005). An alternative technique to determine the distribution of trace elements between melt and minerals involves laboratory crystal growth studies using either natural glasses (i.e., Hart and Dunn, 1993; Aigner-Torres et al., 2007), natural glasses enriched in trace elements (i.e., Adam et al., 1993; Adam and Green, 1994; Forsythe et al., 1994), or simple synthetic systems doped with trace elements (i.e., Shimizu, 1974; Zielinski and Frey, 1974; Gaetani and Grove, 1995; Lundstrom et al., 1998; Ayers and Luo, 2008). These various methods have been used to determine partition coefficients for a large number of elements in a variety of melt compositions. It is well known that partition coefficients vary as a function of many factors, including $P$, $T$, mineral and melt composition, and $\mathrm{H}_{2} \mathrm{O}$-content of the melt (Wood and Blundy, 2003), and this results in a wide range in reported partition coefficients, even for melt-mineral systems that appear to have had similar histories. This variability in turn results in a wide range of inferred parental melt compositions and magma evolution trends based on analyses of natural phenocrysts.

Recently, the melt inclusion-mineral (MIM) technique was introduced to determine partitioning behavior ( $\mathrm{Lu}$ et al., 1992; Sobolev et al., 1996; Thomas et al., 2002, 2003; Zajacz and Halter, 2007). With this technique, the trace element abundances of melt inclusions (MI) and the immediately adjacent host crystal are measured and this information is used to calculate partition coefficients. It has only become possible to apply this technique in recent years following the introduction of microanalytical techniques such as Secondary Ion Mass Spectrometry (SIMS), Proton-Induced X-ray Emission spectroscopy (PIXE), and laser ablation-inductively coupled plasma mass spectrometry (LA-ICPMS) that offer spatial resolutions on the order of $10 \mu \mathrm{m}$ and highly precise and accurate analytical results. The MIM technique has the additional advantage that natural crystals and their parent melts with natural trace element abundances are analyzed. Moreover, the melt in the inclusion represents a sample of the melt phase from which the immediately adjacent host crystal was precipitating, thereby suggesting a close approximation to chemical equilibrium. In this study, the abundances of LILE, HFSE, and REE in glassy melt inclusions hosted in plagioclase, orthopyroxene, and clinopyroxene were determined and the data used to calculate partition coefficients between these minerals and dacitic silicate melt.

\section{GEOLOGIC BACKGROUND}

Samples used in this study were from a recent (1988) eruption at White Island, New Zealand. White Island is an active andesitic-dacitic volcano located in the Bay of Plenty at the northern end of the Taupo Volcanic Zone (TVZ) on the North Island (Cole and Nairn, 1975). The North Island of New Zealand is part of the active boundary where the Pacific plate is being subducted beneath the Australian plate (Isacks et al., 1968). Volcanoes located within the $250 \mathrm{~km}$ long TVZ range from basaltic to rhyolitic in composition. White Island has been volcanically active for at least 10,000 years based on sediment analyses and the extent of hydrothermal activity (Giggenbach and Glasby, 1977). Maori legends and European explorers have documented volcanic activity for at least several hundred years, and modern crater building eruptions occurred in 1933, 1947, 1965-1966, 1968, 1971, 1976-1982, and 19861992 (Hougton and Nairn, 1991; Wood and Browne, 1996). The 1976-1982 and 1986-1992 activity is associated with the emplacement of a large body of basaltic andesite magma at about $0.5 \mathrm{~km}$ depth, and the volcanic activity alternated between strombolian and phreatomagmatic eruptive styles (Clark and Cole, 1989; Hougton and Nairn, 1991; Wood and Browne, 1996). The 1988 lavas at White Island are similar to the better-studied 1977 eruptive products that show a range in composition from mafic andesite $\left(56 \mathrm{wt} \% \mathrm{SiO}_{2}\right)$ to dacite $\left(64.3 \mathrm{wt} \% \quad \mathrm{SiO}_{2}\right)$ (Graham and Cole, 1991). The lavas are interpreted to have been erupted from a zoned magma chamber (Graham and Cole, 1991). The samples used in this study were collected by Dr. C. Peter Wood of the Institute of Geological and Nuclear Sciences, Wairakei, New Zealand.

\section{METHODOLOGY}

\subsection{Mineral and melt inclusion petrography}

Samples from the 1988 eruption at White Island consist of vesicular, porphyritic, gray andesite-dacite containing phenocrysts of plagioclase, clinopyroxene, and orthopyroxene in a glassy matrix that contains microlites of the same minerals and magnetite (Rapien, 1998; Rapien et al., 2003). Phenocrysts comprise 50-70 volume percent of the 1988 samples, and the order of abundance of phenocrysts 
is orthopyroxene $>$ plagioclase $>$ clinopyroxene. Crystals were separated from the surrounding matrix by crushing in a mortar with a pestle. Phenocrysts are euhedral to subhedral and range from 0.01 to $1 \mathrm{~mm}$ in size. Orthopyroxene and clinopyroxene phenocrysts show no evidence of chemical zoning. Some plagioclase is zoned when viewed with differential interference contrast microscopy after etching with fluoboric acid (Rapien, 1998) but these crystals show no chemical zoning when analyzed by EPMA. Minor phases include Ti-magnetite and acicular apatite.

Phenocrysts contain both mineral and melt inclusions, with both occurring as isolated inclusions or in Melt Inclusion Assemblages (MIAs, Bodnar and Student, 2006) defin- ing crystal growth zones (Fig. 1A). All three phenocryst phases can be found as inclusions in the other two phases (e.g., orthopyroxene inclusions in plagioclase and clinopyroxene phenocrysts, plagioclase crystals in ortho- and clinopyroxene, etc.) (Fig. 1B-D). Mineral and melt inclusions display similar sizes and shapes and are often difficult to distinguish using optical microscopy. Coexisting mineral and melt inclusions in the same growth zone suggest crystallization of the host phase and precipitation of the mineral inclusions contemporaneously with entrapment of melt inclusions. This observation provides good evidence for chemical equilibrium between the mineral phases and the silicate melt.

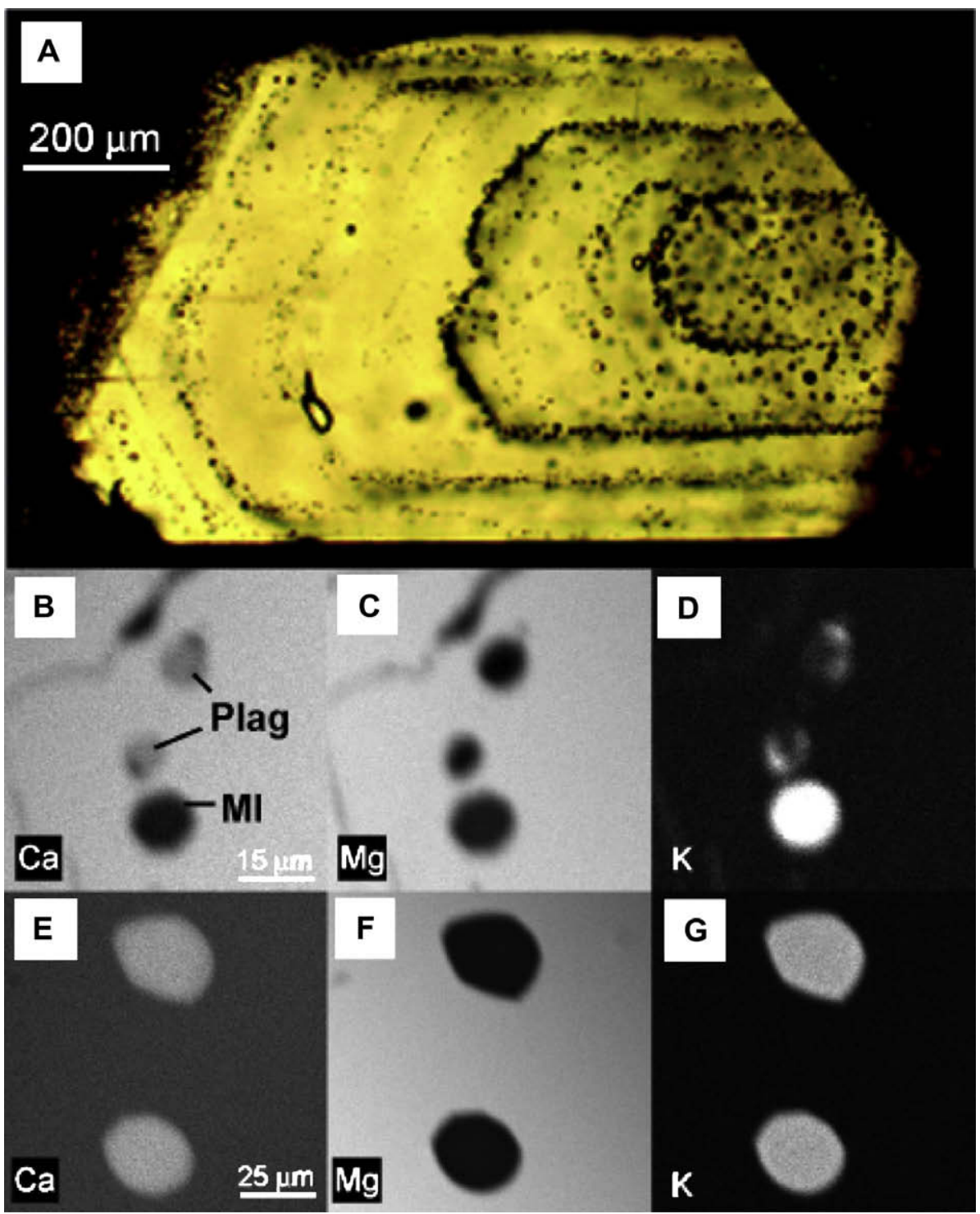

Fig. 1. (A) Photomicrograph of a portion of an orthopyroxene crystal from the 1988 eruption at White Island showing several well-defined crystal growth zones containing mineral and MIs (from Rapien et al., 2003) Photograph taken in transmitted plane-polarized light. (B-D) Electron microprobe X-ray maps for $\mathrm{Ca}, \mathrm{Mg}$, and $\mathrm{K}$ showing a melt inclusion (MI) and two plagioclase inclusions (Plag) in the same growth zone in a clinopyroxene crystal. (E-G) Electron microprobe X-ray maps for $\mathrm{Ca}, \mathrm{Mg}$, and $\mathrm{K}$ showing the chemical homogeneity of two melt inclusions in a growth zone in a clinopyroxene crystal. X-ray maps in (B-G) were collected with a Cameca SX-50 electron microprobe at Virginia Tech using an accelerating voltage of $15 \mathrm{kV}$ and a beam current of $200 \mathrm{nA}$ and operating in beam-scanning mode. 
Mineral and melt inclusions vary in size from $<10$ to $>100 \mu \mathrm{m}$, however, most inclusions are typically between 5 and $30 \mu \mathrm{m}$ (Fig. 1B-G). Generally, isolated inclusions are larger than those in well-defined crystal growth assemblages. Melt inclusions are composed of homogeneous glass with or without a small bubble (Fig. 1E-G), but without any trapped solids or daughter minerals. Melt inclusion shape is rounded to elongate. The melt inclusions are assumed to be primary because they are trapped along crystal growth faces or between growth zones with no visible fractures. Samples from the 1988 eruption were selected because they contain abundant and large glassy melt inclusions with no evidence of devitrification or alteration. A complete description of MI in the sample from the 1988 eruption at White Island is provided by Rapien (1998) and Rapien et al. (2003).

\subsection{Analytical techniques}

Phenocrysts containing melt inclusions were mounted in epoxy, and the melt inclusions were brought close to the surface of the crystal for better visual inspection by controlled grinding and polishing by hand on glass plates (Thomas and Bodnar, 2002). Melt inclusions located along fractures or near the edges of crystals were ignored as were those containing a shrinkage or vapor bubble. Some inclusions were exposed at the surface after polishing while others remained beneath the crystal surface. MI beneath the surface were analyzed by first removing the overlying host by laser ablation, as described below. The major and minor element compositions ( $\mathrm{Si}, \mathrm{Mg}, \mathrm{Ca}, \mathrm{Fe}, \mathrm{Na}, \mathrm{K}, \mathrm{Mn}, \mathrm{P}$, and Ti) of exposed melt inclusions were determined using a Cameca SX-50 electron microprobe (EPMA) at Virginia Tech. For melt inclusion analyses, an accelerating voltage of $15 \mathrm{kV}$ was used with a beam current of $5 \mathrm{nA}$ and beam diameter of $5 \mu \mathrm{m}$ to assure that only glass (melt inclusion) was included in the analytical volume. Using these analytical conditions and measuring $\mathrm{Na}$ and $\mathrm{K}$ first minimizes volatilization of those alkali elements (Student and Bodnar, 1999). Host (plagioclase, clinopyroxene, and orthopyroxene) crystals were analyzed using an accelerating voltage of $15 \mathrm{kV}$, a beam current of $20 \mathrm{nA}$, and beam diameter of $1 \mu \mathrm{m}$. A small beam diameter was used to minimize the effects of chemical zoning in the host and to include in the analytical volume only a small portion of the host immediately adjacent to the melt inclusion, as this most closely represents the composition of the crystal that was forming at the time the melt inclusion was trapped (i.e., the crystal in contact with the melt inclusion most closely approximates the crystal that was in equilibrium with the melt at the time of trapping). Precision of major element data is approximately $2 \%$ relative, and minor element precision is approximately $5 \%$ relative based upon multiple analyses.

Major and minor element abundances of some minerals and MI were measured by EPMA, and all major, minor, and trace element abundances of minerals and melt inclusions were determined by LA-ICPMS. All melt inclusions analyzed in this study were exposed at the surface either by hand polishing or by ablating the host overlying the melt inclusion prior to analysis (as described below) eliminating the need to make a host correction (Halter et al., 2002). LAICPMS analyses were conducted at Virginia Tech using an Agilent 7500ce quadrupole ICPMS and a Lambda Physik GeoLas $193 \mathrm{~nm}$ excimer laser ablation system coupled to an Olympus petrographic microscope equipped with a $25 \times$ UV and visible Schwarzschild objective $(\mathrm{NA}=0.4)$ for analysis, plus $5 \times$ and $10 \times$ objectives for sample viewing. The He gas flow was $\sim 60 \mathrm{~mL} / \mathrm{min}$ through an ablation cell with a volume of $\sim 1 \mathrm{~cm}^{3}$. Dwell times were $10 \mathrm{~ms}$ for all elements and the oxide production rate was less than $1 \%$ [Additional information concerning the LA-ICPMS system is available at: http://www.geochem.geos.vt.edu/fluids/.]. NIST 610 standard reference material (SRM) glass was analyzed two times before and after each analytical session that included 15-20 inclusions plus host phase and was used as the standard for data reduction and for drift correction (see Mutchler et al., 2008). Analyses of the NIST glass were accomplished using a discharge voltage of the laser of $27 \mathrm{kV}$ and a pulse rate of $15 \mathrm{~Hz}$. The energy density at the sample is a function of the aperture and attenuator settings which, for the analytical conditions used here, results in an energy density on the sample of about $10 \pm 3 \mathrm{~J} / \mathrm{cm}^{2}$. Most inclusions and host phases were analyzed using a beam diameter of $24 \mu \mathrm{m}$. The same analytical conditions were used for melt inclusion and host analyses except that a pulse rate of $5 \mathrm{~Hz}$ was used for the host to improve signal stability, and the aperture for the laser spot was adjusted such that the melt inclusion was always larger than the spot size (i.e., the beam was entirely within the melt inclusion). Isotopes analyzed included ${ }^{23} \mathrm{Na},{ }^{25} \mathrm{Mg},{ }^{27} \mathrm{Al},{ }^{28} \mathrm{Si},{ }^{39} \mathrm{~K}$, ${ }^{40} \mathrm{Ca},{ }^{45} \mathrm{Sc},{ }^{49} \mathrm{Ti},{ }^{51} \mathrm{~V},{ }^{55} \mathrm{Mn},{ }^{88} \mathrm{Sr},{ }^{89} \mathrm{Y},{ }^{90} \mathrm{Zr},{ }^{93} \mathrm{Nb},{ }^{138} \mathrm{Ba}$, ${ }^{139} \mathrm{La},{ }^{143} \mathrm{Nd},{ }^{147} \mathrm{Sm},{ }^{153} \mathrm{Eu},{ }^{157} \mathrm{Gd},{ }^{163} \mathrm{Dy},{ }^{165} \mathrm{Ho},{ }^{172} \mathrm{Yb}$, ${ }^{178} \mathrm{Hf}$, and ${ }^{208} \mathrm{~Pb}$.

For each LA-ICPMS analysis, a baseline signal was collected for approximately $30-40 \mathrm{~s}$ before the laser shutter was opened to begin to ablate the melt inclusion or host

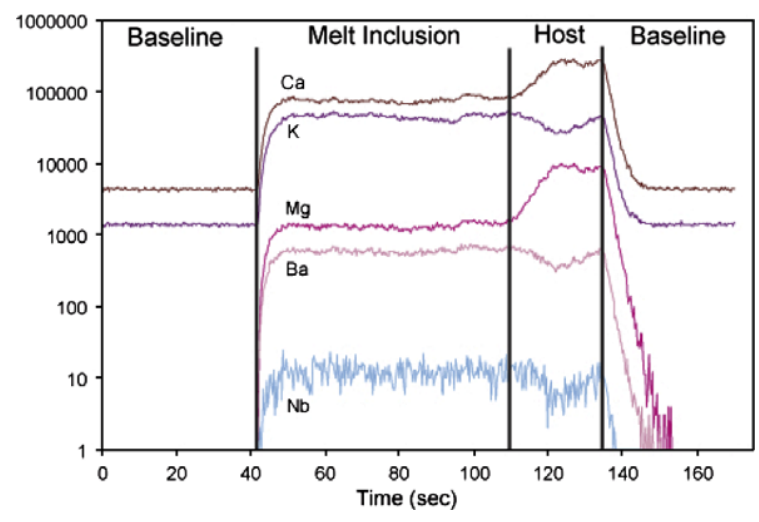

Fig. 2. Time-resolved LA-ICPMS spectrum obtained from a clinopyroxene-hosted MI that is exposed at the surface. During the analysis, a baseline is collected for approximately $40 \mathrm{~s}$ before the shutter to the laser is opened (vertical line at $40 \mathrm{~s}$ ). As MI glass is ablated, the intensities of those elements that are contained in the MI increase and reach an approximately constant value as long as MI glass is being ablated. After approximately $110 \mathrm{~s}$ the laser has ablated completely through the MI and begins to ablate clinopyroxene host that is beneath the MI. After approximately $135 \mathrm{~s}$ the ablation is stopped and the signal returns to baseline levels. 
(Fig. 2). For analyses of melt inclusions exposed at the surface, the laser spot size was adjusted such that the entire spot was within the MI. The ablation process was continued until the ablation pit traversed from the melt inclusion into the underlying host crystal. The ablation was stopped after a few 10 s of seconds of host ablation and the signal was collected until intensities returned to baseline levels (Fig. 2). The initial few seconds of data from each melt inclusion analysis were not included in data reduction to avoid possible errors from contamination on the sample surface from airborne particles or previously ablated material deposited onto the surface - only the relatively stable, flat-topped portion of the ablation spectrum was used to calculate element abundances. Analyses of the host phase were made by placing the laser spot completely in the host mineral and as close to the melt inclusion/host boundary as feasible.
Some inclusions were exposed at the surface by hand polishing and were analyzed as described above, while other melt inclusions remained covered by $\leqslant 100 \mu \mathrm{m}$ of the host phase when the sample was placed into the laser ablation cell. Inclusions beneath the crystal surface were exposed by ablating the host using a laser pulse rate of $5 \mathrm{~Hz}$ and a laser spot size significantly larger than the melt inclusion. This technique was used to remove host material covering the buried MI to expose the inclusion at the bottom of a cylindrical hole that was about twice the diameter of the MI as observed in the plane of the sample surface. To expose the MI, the laser was fired 5-10 times and the sample was then examined optically. If the inclusion was not exposed at the center of the laser crater, then another sequence of 5-10 laser pulses was applied and the inclusion re-examined. This process was repeated until the MI was exposed and clearly visible at the bottom of the ablation

Table 1

Average major and trace element compositions of host minerals.

\begin{tabular}{|c|c|c|c|c|c|c|}
\hline EPMA & $\mathrm{CPX}(8)^{\mathrm{a}}$ & SD & $\operatorname{OPX}(3)^{\mathrm{a}}$ & SD & Plag $(3)^{\mathrm{a}}$ & SD \\
\hline $\mathrm{SiO}_{2}$ & 52.69 & 0.25 & 54.32 & 0.27 & 52.98 & 0.58 \\
\hline $\mathrm{TiO}_{2}$ & 0.43 & 0.06 & 0.27 & 0.01 & 0.06 & 0.02 \\
\hline $\mathrm{Al}_{2} \mathrm{O}_{3}$ & 2.11 & 0.30 & 1.38 & 0.25 & 28.46 & 0.19 \\
\hline $\mathrm{FeO}$ & 8.90 & 0.78 & 15.65 & 0.46 & 0.84 & 0.21 \\
\hline $\mathrm{MnO}$ & 0.23 & 0.02 & 0.34 & 0.02 & 0.02 & 0.01 \\
\hline $\mathrm{MgO}$ & 16.15 & 0.73 & 24.86 & 0.40 & 0.19 & 0.02 \\
\hline $\mathrm{CaO}$ & 18.22 & 0.54 & 2.48 & 0.70 & 13.12 & 0.61 \\
\hline $\mathrm{Na}_{2} \mathrm{O}$ & 0.26 & 0.06 & 0.12 & 0.08 & 3.49 & 0.20 \\
\hline $\mathrm{K}_{2} \mathrm{O}$ & 0.03 & 0.05 & 0.07 & 0.07 & 0.26 & 0.05 \\
\hline $\mathrm{NiO}$ & 0.03 & 0.01 & 0.06 & 0.02 & 0.01 & 0.01 \\
\hline Total & 99.05 & 0.40 & 99.56 & 0.19 & 99.44 & 0.53 \\
\hline LA-ICPMS ${ }^{b}$ & $\operatorname{CPX}(9)^{\mathrm{a}}$ & SD & $\operatorname{OPX}(8)^{\mathrm{a}}$ & SD & Plag $(5)^{\mathrm{a}}$ & SD \\
\hline $\mathrm{SiO}_{2}$ & 53.62 & 0.694 & 56.183 & 1.595 & 52.571 & 2.593 \\
\hline $\mathrm{TiO}_{2}$ & 0.38 & 0.060 & 0.226 & 0.014 & 0.047 & 0.006 \\
\hline $\mathrm{Al}_{2} \mathrm{O}_{3}$ & 2.00 & 0.127 & 1.260 & 0.042 & 31.280 & 1.839 \\
\hline $\mathrm{FeO}$ & 8.98 & 1.377 & 15.465 & 0.713 & 0.639 & 0.025 \\
\hline $\mathrm{MnO}$ & 0.23 & 0.032 & 0.334 & 0.019 & 0.004 & 0.001 \\
\hline $\mathrm{MgO}$ & 15.88 & 0.648 & 24.604 & 1.038 & 0.154 & 0.006 \\
\hline $\mathrm{CaO}$ & 18.51 & 1.206 & 12.0 & 0.085 & 12.006 & 0.910 \\
\hline $\mathrm{Na}_{2} \mathrm{O}$ & 0.218 & 0.016 & 0.038 & 0.008 & 3.017 & 0.173 \\
\hline $\mathrm{K}_{2} \mathrm{O}$ & 0.01 & 0.005 & 0.007 & 0.007 & 0.213 & 0.015 \\
\hline $\mathrm{Sc}^{\mathrm{c}}$ & 122.89 & 5.940 & & & & \\
\hline $\mathrm{V}^{\mathrm{c}}$ & 523.229 & 36.67 & & & & \\
\hline $\mathrm{Sr}$ & 12.30 & 0.78 & 0.47 & 0.20 & 349.40 & 22.74 \\
\hline $\mathrm{Y}$ & 21.74 & 3.71 & 4.35 & 0.30 & 0.37 & 0.16 \\
\hline $\mathrm{Zr}$ & 15.23 & 2.46 & 2.81 & 0.47 & 1.06 & 0.90 \\
\hline $\mathrm{Nb}$ & 0.03 & 0.01 & 0.05 & 0.04 & 0.06 & 0.04 \\
\hline $\mathrm{Ba}$ & 1.30 & 1.12 & 1.98 & 0.88 & 172.26 & 15.28 \\
\hline $\mathrm{La}$ & 1.00 & 0.17 & 0.04 & 0.02 & 1.47 & 0.25 \\
\hline $\mathrm{Nd}$ & 5.33 & 1.15 & 0.21 & 0.08 & 1.10 & 0.36 \\
\hline $\mathrm{Sm}$ & 2.21 & 0.41 & 0.14 & 0.05 & 0.15 & 0.04 \\
\hline $\mathrm{Eu}$ & 0.53 & 0.10 & 0.04 & 0.03 & 0.43 & 0.04 \\
\hline $\mathrm{Gd}$ & 3.32 & 0.69 & 0.25 & 0.08 & 0.21 & 0.14 \\
\hline Dy & 4.00 & 0.78 & 0.58 & 0.10 & 0.10 & 0.07 \\
\hline Ho & 0.85 & 0.12 & 0.18 & 0.04 & 0.02 & 0.01 \\
\hline $\mathrm{Yb}$ & 2.43 & 0.47 & 0.85 & 0.11 & 0.03 & 0.02 \\
\hline Hf & 0.72 & 0.15 & 0.15 & 0.04 & 0.04 & 0.02 \\
\hline $\mathrm{Pb}$ & 0.13 & 0.06 & 0.18 & 0.09 & 1.53 & 0.17 \\
\hline
\end{tabular}

${ }^{\text {a }}$ Number in parenthesis represents the number of analyses.

b Major elements in $\mathrm{wt}_{\mathrm{t}} \%$; trace elements in $\mathrm{ppm}$.

${ }^{c}$ Based upon four analyses. 
Table 2

Average major and trace element compositions of melt inclusions

\begin{tabular}{|c|c|c|c|c|c|c|}
\hline EPMA & $\operatorname{CPXMI}(7)^{\mathrm{a}}$ & $\mathrm{SD}$ & OPX MI $(3)^{\mathrm{a}}$ & $\mathrm{SD}$ & Plag MI $(5)^{\mathrm{a}}$ & $\mathrm{SD}$ \\
\hline $\mathrm{SiO}_{2}$ & 65.39 & 1.33 & 65.57 & 0.93 & 66.06 & 0.84 \\
\hline $\mathrm{TiO}_{2}$ & 0.98 & 0.19 & 1.09 & 0.14 & 1.11 & 0.22 \\
\hline $\mathrm{FeO}$ & 6.10 & 0.49 & 6.82 & 0.07 & 6.07 & 0.43 \\
\hline $\mathrm{MnO}$ & 0.08 & 0.03 & 0.09 & 0.02 & 0.09 & 0.03 \\
\hline $\mathrm{MgO}$ & 2.32 & 1.36 & 2.02 & 0.80 & 2.12 & 0.16 \\
\hline $\mathrm{K}_{2} \mathrm{O}$ & 1.81 & 0.46 & 1.96 & 0.61 & 2.05 & 0.06 \\
\hline $\mathrm{Na}_{2} \mathrm{O}$ & 2.48 & 0.15 & 2.64 & 0.17 & 2.94 & 0.04 \\
\hline $\mathrm{NiO}$ & 0.04 & 0.02 & 0.03 & 0.01 & 0.04 & 0.02 \\
\hline Total & 98.20 & 0.55 & 98.99 & 0.00 & 98.50 & 0.41 \\
\hline LA-ICPMS ${ }^{b}$ & $\operatorname{CPXMI}(22)^{\mathrm{a}}$ & $\mathrm{SD}$ & OPX MI $(27)^{\mathrm{a}}$ & $\mathrm{SD}$ & Plag MI (23) & $\mathrm{SD}$ \\
\hline $\mathrm{SiO}_{2}$ & 65.44 & 2.37 & 64.98 & 2.70 & 65.28 & 1.68 \\
\hline $\mathrm{Al}_{2} \mathrm{O}_{3}$ & 15.96 & 1.55 & 16.29 & 1.68 & 15.90 & 1.46 \\
\hline $\mathrm{FeO}$ & 5.68 & 1.90 & 5.64 & 0.99 & 5.39 & 0.40 \\
\hline $\mathrm{MnO}$ & 0.08 & 0.02 & 0.08 & 0.01 & 0.08 & 0.01 \\
\hline $\mathrm{MgO}$ & 1.66 & 0.39 & 1.79 & 0.63 & 1.88 & 0.15 \\
\hline $\mathrm{CaO}$ & 4.42 & 1.17 & 4.91 & 1.01 & 4.84 & 0.63 \\
\hline $\mathrm{K}_{2} \mathrm{O}$ & 3.10 & 1.03 & 2.41 & 0.48 & 2.39 & 0.24 \\
\hline $\mathrm{Na}_{2} \mathrm{O}$ & 2.61 & 0.17 & 2.77 & 0.22 & 3.00 & 0.13 \\
\hline $\mathrm{Sc}^{\mathrm{c}}$ & 38.18 & 5.23 & & & & \\
\hline $\mathrm{V}^{\mathrm{c}}$ & 350.46 & 17.21 & & & & \\
\hline $\mathrm{Sr}$ & 132.32 & 30.90 & 154.45 & 31.93 & 144.54 & 19.16 \\
\hline $\mathrm{Y}$ & 23.43 & 9.97 & 27.09 & 5.39 & 28.66 & 5.98 \\
\hline $\mathrm{Zr}$ & 164.62 & 31.22 & 180.16 & 44.28 & 220.21 & 53.17 \\
\hline $\mathrm{Nb}$ & 5.69 & 1.79 & 5.52 & 1.36 & 6.85 & 2.08 \\
\hline $\mathrm{Ba}$ & 996.25 & 186.36 & 908.98 & 98.12 & 909.47 & 89.85 \\
\hline $\mathrm{La}$ & 13.07 & 3.50 & 14.86 & 3.04 & 16.30 & 2.68 \\
\hline $\mathrm{Eu}$ & 0.92 & 0.30 & 0.97 & 0.57 & 1.05 & 0.21 \\
\hline Gd & 3.79 & 1.85 & 4.76 & 2.21 & 4.51 & 1.14 \\
\hline Dy & 4.45 & 1.58 & 4.66 & 1.63 & 5.07 & 1.13 \\
\hline Ho & 0.89 & 0.33 & 0.97 & 0.58 & 1.04 & 0.25 \\
\hline $\mathrm{Yb}$ & 2.60 & 0.99 & 2.67 & 0.77 & 3.41 & 0.81 \\
\hline Hf & 4.84 & 2.12 & 5.07 & 1.15 & 5.59 & 1.71 \\
\hline $\mathrm{Pb}$ & 10.95 & 1.89 & 11.41 & 2.30 & 11.91 & 1.38 \\
\hline
\end{tabular}

a Number in parenthesis represents the number of analysis.

b Major elements in $\mathrm{wt}^{\%} \%$; trace elements in $\mathrm{ppm}$.

c Based upon four analyses.

pit. A unique feature of the Virginia Tech LA-ICPMS instrument that facilitates this process is that the sample stage is mounted on a research-grade petrographic microscope equipped with high quality reflected and transmitted light optics, which allows samples to be examined at various magnifications before and after ablation. After the signal returned to background level following this episode of "drilling" to expose the MI, the laser spot size was reduced such that it was contained entirely within the inclusion. This assured that only the MI would be sampled during the subsequent analysis. Within an MIA, the compositions of MI were consistent, independent of whether the MI was originally exposed at the crystal surface or was buried and exposed by "drilling" as described above.

The analytical conditions for the host mineral and MIs were the same, except that the minerals were analyzed for
20-30 s at each spot. Three or four analyses of the host mineral immediately adjacent to the MI were conducted to test for homogeneity in the host mineral composition. Several areas were analyzed for major and minor elements by both EPMA and LA-ICPMS to test for consistency between the two techniques, and the results are shown in Tables 1 and 2. Compositional data from EPMA analyses were used as an internal standard for the LA-ICPMS analyses. The LA-ICPMS data were also reduced assuming $100 \%$ oxides, and the results were identical within analytical error to the values determined using the internal EPMA standard. Most MI were only analyzed by LA-ICPMS and the data were reduced assuming $100 \%$ oxides. The time-resolved LA-ICPMS data were reduced using AMS analytical software (Mutchler et al., 2007; Mutchler et al., 2008). 


\section{RESULTS}

\subsection{Mineral compositions}

Major element compositions of host crystals are shown in Fig. 3A (pyroxene) and 3B (plagioclase), and listed in Table 1. Also shown on Fig. 3A and B are the results from Rapien (1998) for samples from this same eruptive unit. The clinopyroxenes have an average augitic composition of $\mathrm{En}_{47} \mathrm{Fs}_{13} \mathrm{Wo}_{40}$, and orthopyroxenes have an average composition of $\mathrm{En}_{71} \mathrm{Fs}_{27} \mathrm{Wo}_{2}$ and these compositions are consistent with those from other island arc calc-alkaline andesitic rocks (Wilson, 1994). Plagioclase compositions are slightly more Ca-rich than compositions reported by Rapien et al. (2003), with an average composition of $\mathrm{An}_{67} \mathrm{Ab}_{31} \mathrm{Or}_{2}$.

Trace element data for the host minerals are summarized in Fig. 4. Plagioclase is enriched in LREE relative to HREE and shows a large positive Eu anomaly (Fig. 4A). Clinopyroxene displays a concave-down REE pattern, with the middle REEs slightly enriched over both LREE and HREE (Fig. 4A). Orthopyroxene is relatively enriched in HREE relative to LREE (Fig. 4A). Plagioclase is enriched in $\mathrm{K}$, $\mathrm{Sr}, \mathrm{Ba}$, and $\mathrm{Pb}$ and depleted in $\mathrm{Y}, \mathrm{Ti}, \mathrm{Zr}$, and $\mathrm{Hf}$ compared

A

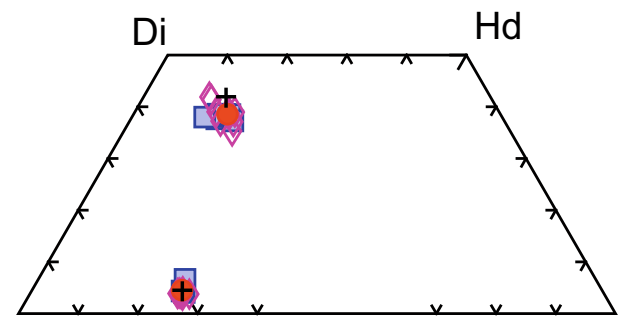

En

$\mathrm{FS}$

B

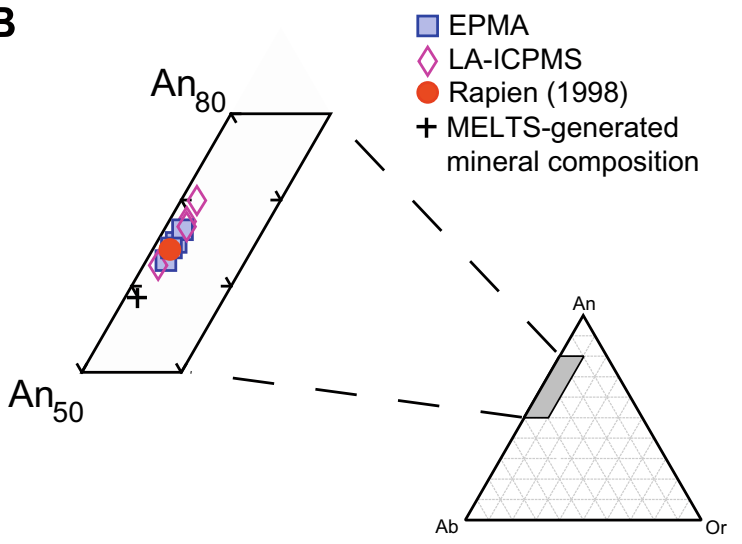

Fig. 3. Compositions of pyroxene (A) and plagioclase (B) determined by EPMA (filled squares) and LA-ICPMS (open diamonds). (A) Pyroxene quadrilateral showing the compositions of the host clinopyroxene and orthopyroxene. Also shown are the average compositions determined by Rapien (1998), represented by the filled circle. (B) The anorthite-rich portion of the feldspar CNK ternary showing compositions of host plagioclase. The average composition of plagioclase, clinopyroxene and orthopyroxene reported by Rapien (1998) and compositions of these minerals predicted by MELTS modeling are also shown.
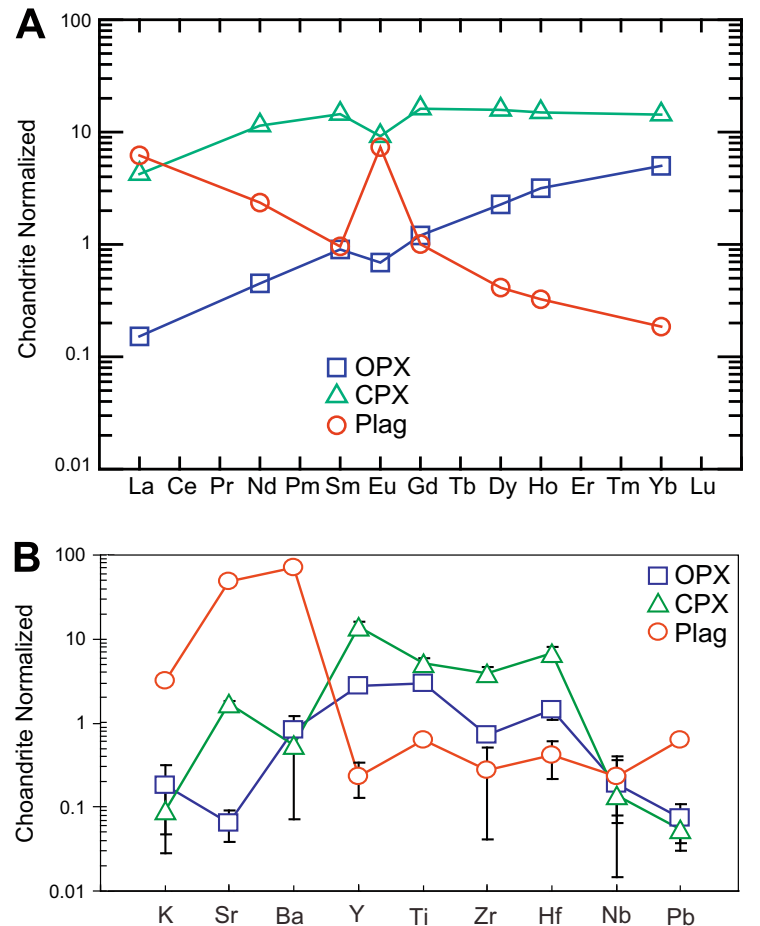

Fig. 4. Chondrite normalized (Sun and McDonough, 1989) average REE (A), HFSE (B) and LILE (B) abundances of host crystals. $2 \sigma$ standard deviations are smaller than the symbol size in (A) and are represented by the vertical bars in (B).

to both pyroxenes (Fig. 4B). The trace element patterns obtained are typical of trace element patterns in plagioclase and ortho- and clinopyroxenes from andesitic to rhyolitic melts (Rollinson, 1993). Trace element zoning or heterogeneity was not observed in either pyroxenes or plagioclase.

\subsection{Melt compositions}

Average compositions of MI hosted in clinopyroxene, orthopyroxene and plagioclase determined using EPMA and LA-ICPMS are listed in Table 2. Compositions of MI from all three phenocryst minerals are identical within analytical error, confirming that all three were co-precipitating from the same melt (Rapien, 1998; Wardell et al., 2001). In terms of major element chemistry, the MIs resemble typical calc-alkaline dacites (Fig. 5) (Rollinson, 1993). Rapien et al. (2003) reported $\mathrm{H}_{2} \mathrm{O}$ contents ranging from 0.36 to $0.89 \mathrm{wt} \%$ for melt inclusions in pyroxenes from the 1988 eruption and Wardell et al. (2001) reported an $\mathrm{H}_{2} \mathrm{O}$ content of $0.6 \mathrm{wt} \%$ from melt inclusions from the 1989 eruption. All MI examined in this study are assumed to contain $<1 \mathrm{wt} \% \mathrm{H}_{2} \mathrm{O}$.

The most striking aspect of the trace element chemistry of the MIs is their uniformity. Despite being hosted in minerals with a wide range in trace element chemistries (Fig. 4), the trace element compositions of the MIs are, within analytical error, identical (Fig. 6). The MIs are slightly enriched in LREE, show a small negative Eu anomaly, and display a flat chondrite-normalized pattern for HREE (Fig. 6A). Negative anomalies in $\mathrm{Sr}, \mathrm{Eu}$, and (possibly) $\mathrm{Pb}$ probably 


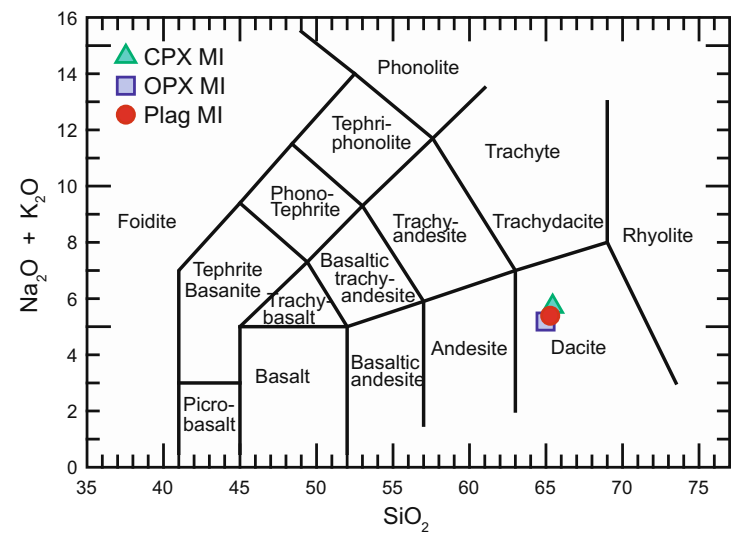

Fig. 5. Mean MI compositions determined by LA-ICPMS plotted on the total alkali versus silica diagram. $2 \sigma$ standard deviations are smaller than the symbol size.
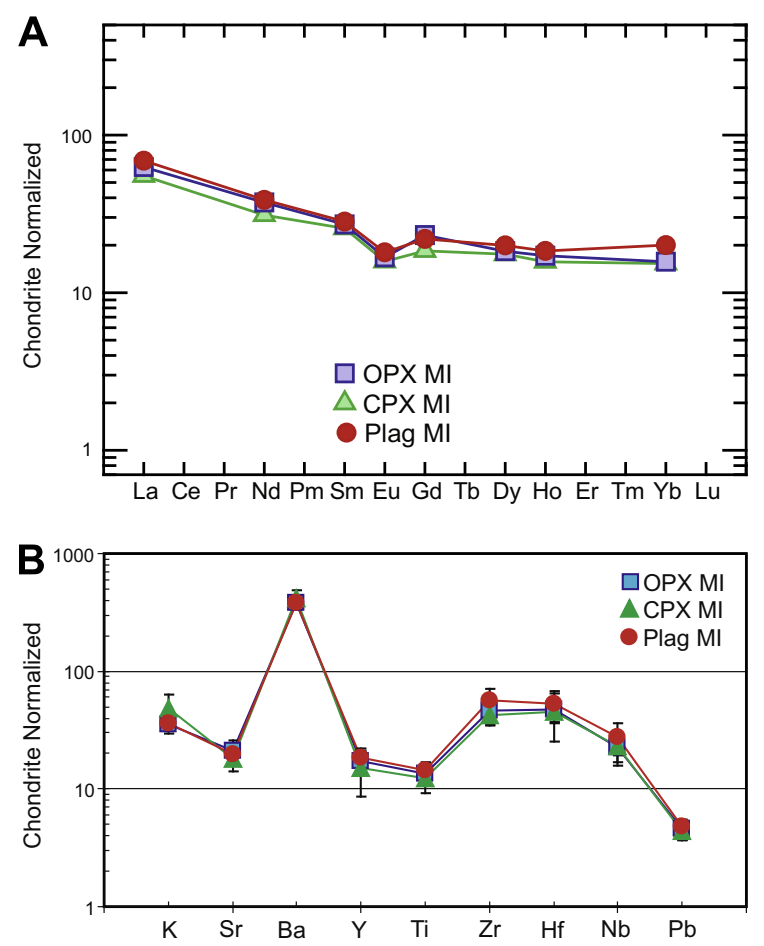

Fig. 6. Chondrite normalized (Sun and McDonough 1989) average REE (A), HFSE (B), and LILE (B) abundances of melt inclusions. $2 \sigma$ standard deviations are smaller than the symbol size in (A) and are either smaller than the symbol size or represented by the vertical bars in (B).

reflect plagioclase fractionation (Bacon, 1990), and the trace element characteristics of the MIs are typical of arc magmas (Rollinson, 1993; Wilson, 1994).

To test the hypothesis that MIs trapped in plagioclase, clinopyroxene and orthopyroxene are indeed recording the evolution of an andesitic melt that was crystallizing clinopyroxene, orthopyroxene and plagioclase along a cotectic, experiments were conducted using the MELTS model that simulates crystallization of silicate melts (Ghiorso and Sack, 1995; Asimow and Ghiorso, 1998).
The starting composition selected is the mafic andesite erupted at White Island in 1977 (Graham and Cole, 1991). Conditions selected for the simulation and results are reported in Table 3.

Results from MELTS indicate that the andesitic magma, containing approximately $1 \% \mathrm{H}_{2} \mathrm{O}$, underwent fractional crystallization at a pressure of about $1 \mathrm{kbar}$ at an oxygen fugacity approximated by the QFM +1 buffer. The composition of the melt remaining after $50 \%$ crystallization shows good agreement with the compositions of MI from White Island (Table 3). Equilibrium compositions of orthopyroxene and clinopyroxene predicted by MELTS show excellent agreement with measured compositions (Fig. 3), in spite of the fact that MELTS generally does not predict pyroxene compositions that are consistent with experimental phase equilibrium data (Yang et al., 1996). Plagioclase compositions predicted by MELTS are slightly less anorthitic than those analyzed from White Island (Fig. 3). Recently, Fowler et al. (2007) used MELTS to model the evolution of the Campanian Ignimbrite (Campania, Italy) and reported a similar difference between observed and modeled plagioclase compositions, which they interpreted to be the result of wall-rock assimilation. Overall, the results of MELTS simulations reproduced reasonably well the White Island MI and host mineral compositions (Table 3 and Figs. 3-6). The results are consistent with our interpretation that the melt trapped in White Island MIs represents an evolved stage of crystallization ( $\sim 50 \%$ of melt crystallized) of an andesitic melt that was crystallizing cotectic plagioclase, clinopyroxene, and orthopyroxene.

\subsection{Partition coefficients}

Partition coefficients $\left(D_{i}\right)$ were calculated from individual MI-mineral pairs. The average partition coefficients for the three different White Island phenocryst-melt pairs, and published partitioning data for pyroxene and plagioclase in andesite, dacite, and low-Si rhyolite are listed in Table 4 and summarized in Fig. 7. For most trace elements, the partition coefficients determined in this study using the MIM technique fall within the lower portion of the range of literature values (Fig. 7).

\section{DISCUSSION}

\subsection{MIM technique}

The melt inclusion-mineral (MIM) technique for determining partitioning behavior of trace elements can provide precise and accurate results for many mineral-melt pairs (Thomas et al., 2002, 2003; Zajacz and Halter, 2007). However, one should be cognizant of the fact that partition coefficients obtained using the MIM technique may be subject to errors resulting from natural processes and analytical procedures. These include: (1) the possibility of contamination by the host mineral; (2) post-entrapment crystallization and fractionation of the melt; (3) post-entrapment exchange of $\mathrm{Fe}$ and $\mathrm{Mg}$ in mafic minerals and; and (4) the possibility that a substantial portion of the inclusion represents a disequilibrium boundary layer formed at the time of crystalli- 
Table 3

Summary of MELTS modeling of the crystallization of White Island andesite melt.

\begin{tabular}{|c|c|c|c|c|c|c|c|c|c|}
\hline \multirow{2}{*}{$\begin{array}{l}\text { F.C. } P=1 \text { kbar } \\
\text { QFM }+1^{\text {a }}\end{array}$} & \multirow[t]{2}{*}{ Starting comp. ${ }^{\mathrm{b}}$} & \multirow{2}{*}{$\begin{array}{l}\text { Melt comp. } \\
\text { at } \sim 50 \% \\
\text { F.C. }\end{array}$} & \multicolumn{3}{|c|}{ Eq. assemb. at $\sim 50 \%$ fract. $^{d}$} & \multirow{2}{*}{$\begin{array}{l}\text { Avg. comp. } \\
\text { WI MI }\end{array}$} & \multicolumn{3}{|c|}{ Avg. comp. host phases WI ${ }^{f}$} \\
\hline & & & PLAG & CPX & OPX & & PLAG & CPX & OPX \\
\hline $\mathrm{SiO}_{2}$ & 57.42 & 65.05 & 50.115 & 50.11 & 53.34 & 65.67 & 52.98 & 52.69 & 54.32 \\
\hline $\mathrm{TiO}_{2}$ & 0.6 & 0.75 & & 0.68 & 0.07 & 1.06 & & 0.43 & 0.27 \\
\hline $\mathrm{Al}_{2} \mathrm{O}_{3}$ & 13.76 & 14.81 & 29.33 & 3.95 & 1.84 & 13.761 & 28.46 & 2.11 & 1.38 \\
\hline $\mathrm{FeO}_{\text {tot }}{ }^{\mathrm{g}}$ & 7.06 & 4.08 & & 10.49 & 17.88 & 6.33 & & 8.9 & 15.65 \\
\hline $\mathrm{MnO}$ & 0.17 & 0.34 & & & & 0.09 & & & \\
\hline $\mathrm{MgO}$ & 7.85 & 1.57 & & 14.46 & 24.92 & 2.16 & & 16.15 & 24.86 \\
\hline $\mathrm{CaO}$ & 8.08 & 4.83 & 11.61 & 19.76 & 1.82 & 4.98 & 13.12 & 18.22 & 2.48 \\
\hline $\mathrm{Na}_{2} \mathrm{O}$ & 2.42 & 3.5 & 4.78 & 0.29 & 0.02 & 2.69 & 3.49 & 0.26 & 0.12 \\
\hline $\mathrm{K}_{2} \mathrm{O}$ & 1.38 & 2.71 & 0.34 & & & 1.94 & 0.26 & & \\
\hline $\mathrm{P}_{2} \mathrm{O}_{5}$ & 0.11 & 0.22 & & & & & & & \\
\hline $\mathrm{H}_{2} \mathrm{O}$ & 0.99 & 2.01 & & & & & & & \\
\hline
\end{tabular}

${ }^{a}$ MELTS model assumed fractional crystallization (F.C.) at 1 kbar and an oxygen fugacity of QFM +1 .

b Starting melt composition is from Graham and Cole (1991 their Table 1, sample no. 17), after adding $1 \% \mathrm{H}_{2} \mathrm{O}$ and normalizing to $100 \%$.

${ }^{\mathrm{c}}$ Composition of the melt phase after $50 \%$ crystallization.

${ }^{\mathrm{d}}$ Compositions of minerals in the equilibrium assemblage after $50 \%$ crystallization; also includes spinel $(\approx 70 \%$ magnetite $)$.

e Average composition of White Island melt inclusions determined in this study.

${ }^{\mathrm{f}}$ Average compositions of orthopyroxene, clinopyroxene and plagioclase from this study.

${ }^{g} \mathrm{FeO}_{\text {tot }}$ calculated from $\mathrm{FeO}$ and $\mathrm{Fe}_{2} \mathrm{O}_{3}$ values from MELTS as: $\mathrm{FeO}_{\text {tot }}=\mathrm{Fe}_{2} \mathrm{O}_{3} / 1.113+\mathrm{FeO}$.

Table 4

Average partition coefficients $(D)$ calculated using individual melt inclusion-host pairs. Also shown are $D$ ranges from the literature.

\begin{tabular}{|c|c|c|c|c|c|c|c|c|c|}
\hline & $\begin{array}{l}\text { CPX } \\
\text { Mean }\end{array}$ & $\begin{array}{l}\text { CPX } \\
\text { SD }\end{array}$ & $\begin{array}{l}\text { CPX } \\
\text { Literature values }\end{array}$ & $\begin{array}{l}\text { OPX } \\
\text { Mean }\end{array}$ & $\begin{array}{l}\text { OPX } \\
\text { SD }\end{array}$ & $\begin{array}{l}\text { OPX } \\
\text { Literature values }\end{array}$ & $\begin{array}{l}\text { PLAG } \\
\text { Mean }\end{array}$ & $\begin{array}{l}\text { PLAG } \\
\text { SD }\end{array}$ & $\begin{array}{l}\text { PLAG } \\
\text { Literature values }\end{array}$ \\
\hline $\mathrm{K}$ & 0.002 & 0.002 & $0.0185-0.056$ & 0.004 & 0.004 & $0.0014-0.016$ & 0.095 & 0.015 & $0.065-0.263$ \\
\hline $\mathrm{Sc}$ & 3.306 & 0.270 & $2.7-65$ & & & & & & \\
\hline $\mathrm{Ti}$ & 0.412 & 0.04 & $0.37-0.615$ & 0.229 & 0.029 & $0.265-0.405$ & 0.043 & 0.006 & $0.0433-0.0485$ \\
\hline V & 1.532 & 0.081 & $1.1-5.2$ & & & & & & \\
\hline $\mathrm{Mn}$ & 2.877 & 0.420 & $1.65-45$ & 4.055 & 0.498 & $2 . .5-45.5$ & 0.060 & 0.009 & $0.038-0.44$ \\
\hline $\mathrm{Sr}$ & 0.101 & 0.023 & $0.0648-0.516$ & 0.003 & 0.002 & $0.005-0.2205$ & 2.422 & 0.258 & $1.55-19.9$ \\
\hline $\mathrm{Y}$ & 0.949 & 0.198 & $0.28-2.7$ & 0.169 & 0.032 & $0.365-0.755$ & 0.012 & 0.005 & $0.01-0.51$ \\
\hline $\mathrm{Zr}$ & 0.097 & 0.024 & $0.162-2.4$ & 0.016 & 0.003 & $0.0305-0.13$ & 0.55 & 0.002 & $0.001-0.55$ \\
\hline $\mathrm{Nb}$ & 0.008 & 0.004 & $0.012-1.0$ & 0.007 & 0.003 & $0.0027-0.78$ & 0.008 & 0.004 & $0.0215-1.3$ \\
\hline $\mathrm{Ba}$ & 0.001 & 0.001 & $0.035-0.33$ & 0.003 & 0.002 & $0.0027-0.56$ & 0.186 & 0.020 & $0.125-1.93$ \\
\hline $\mathrm{La}$ & 0.082 & 0.024 & $0.047-1.23$ & 0.003 & 0.003 & $0.0021-0.78$ & 0.088 & 0.020 & $0.11-0.393$ \\
\hline $\mathrm{Nd}$ & 0.380 & 0.116 & $0.166-1.4$ & 0.014 & 0.008 & $0.016-1.25$ & 0.054 & 0.013 & $0.057-0.189$ \\
\hline $\mathrm{Sm}$ & 0.610 & 0.189 & $0.377-5.95$ & 0.041 & 0.024 & $0.017-1.6$ & 0.033 & 0.015 & $0.0425-0.17$ \\
\hline $\mathrm{Eu}$ & 0.626 & 0.239 & $0.411-4.5$ & 0.052 & 0.052 & $0.028-0.825$ & 0.397 & 0.134 & $0.394-5.85$ \\
\hline $\mathrm{Gd}$ & 0.907 & 0.275 & $0.583-1.41$ & 0.064 & 0.043 & $0.027-0.223$ & 0.037 & 0.025 & $0.039-0.129$ \\
\hline Dy & 0.926 & 0.2 & $0.774-8.4$ & 0.138 & 0.056 & $0.041-1.8$ & 0.013 & 0.007 & $0.0295-0.256$ \\
\hline Ho & 1.009 & 0.246 & 1.04 & 0.199 & 0.068 & 0.52 & 0.017 & 0.006 & \\
\hline $\mathrm{Yb}$ & 0.973 & 0.297 & $0.634-7.55$ & 0.350 & 0.111 & $0.115-2.2$ & 0.010 & 0.005 & $0.013-0.1323$ \\
\hline $\mathrm{Hf}$ & 0.171 & 0.059 & $0.173-0.67$ & 0.032 & 0.017 & $0.031-0.2$ & 0.016 & 0.007 & $0.012-0.175$ \\
\hline $\mathrm{Pb}$ & 0.012 & 0.008 & $0.11-0.63$ & 0.018 & 0.009 & $0.17-0.54$ & 0.134 & 0.028 & $0.23-2.8$ \\
\hline
\end{tabular}

zation. All of these processes would lead to a scatter in the melt inclusion compositions, both within an individual phenocryst type, and between phenocryst types. At White Island, MI compositions do not vary within a phenocryst type or between mineral hosts (Table 2 and Fig. 6), effectively precluding the involvement of any of the processes listed above. For example, $\mathrm{MgO}$ abundance in plagioclase-hosted MI is neither higher nor lower than MI in pyroxene. If some pyroxene host had been included in the melt inclusion analyses, the concentration of $\mathrm{MgO}$ in $\mathrm{MI}$ in pyroxene would appear to be higher than its concentration in MI in plagioclase.
If MI cool slowly after trapping, some material may crystallize on the inclusion walls or daughter minerals may precipitate from the melt, thus changing the composition of the remaining melt (glass) in the MI (Danyushevsky et al., 2000; Gaetani and Watson, 2000; Danyushevsky et al., 2002; Bodnar and Student, 2006). If a significant amount of melt had crystallized on the inclusion walls following trapping, $\mathrm{MgO}$ would be lower in melt inclusions in pyroxene compared to MI in plagioclase. Similar arguments can be made for $\mathrm{Sr}$ and $\mathrm{Al}$ in plagioclase and for $\mathrm{Ca}$ in both plagioclase and clinopyroxene. Because the White Island MIs were rapidly cooled from the trapping 
temperature during an explosive eruption to produce a homogeneous quenched melt (glass), crystallization of the mineral host on the inclusion walls is unlikely.

Diffusive exchange of $\mathrm{Fe}, \mathrm{Ti}$, and $\mathrm{Si}$ between MIs and the host has been suggested in other studies based on compositional differences between MIs hosted in different mineral phases from the same sample (Danyushevsky et al., 2002). This process does not, however, seem to have affected the MI in this study as the Fe, $\mathrm{Ti}$, and $\mathrm{Si}$ abundances in MI from the 1988 eruption at White Island do not vary with host phase (Table 2 and Fig. 6).

The lack of correlation between MI chemistry and host mineralogy also precludes modification of trace element abundances as a result of boundary layer processes. Boundary layers may develop when the crystal growth rate is faster than the rate of diffusion of cations towards or away from the crystal-melt interface (Bacon, 1989; Baker, 2008). The result is the development of a zone immediately adjacent to the growing crystal that is enriched in incompatible elements that are unable to diffuse away from the crystal fast enough to maintain a constant composition in the melt phase, or depleted in compatible elements that cannot diffuse to the growing crystal surface fast enough to compensate for the fact that they are being removed from the melt by crystal growth. If boundary layers develop at the crystal-melt interface, and if the melt at the interface

A

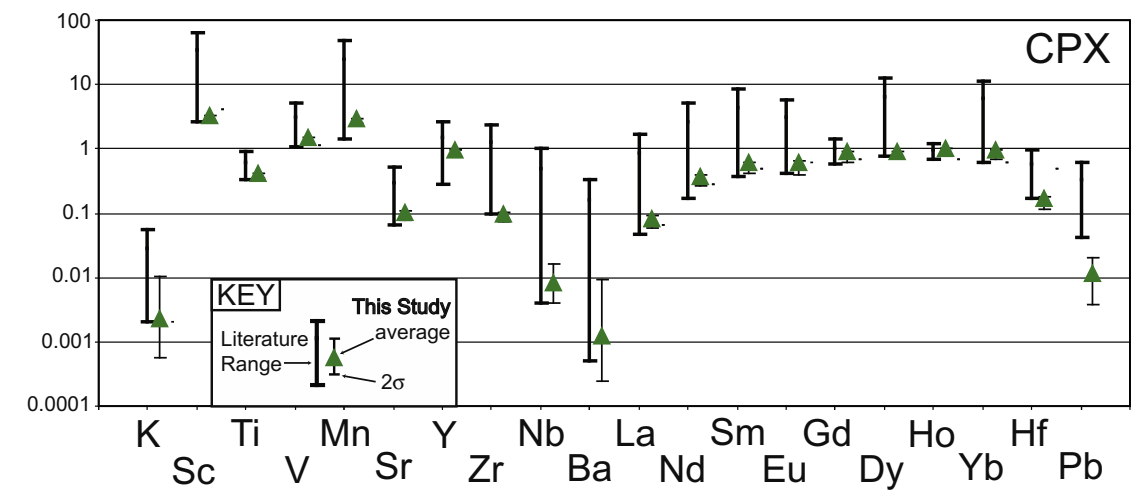

B
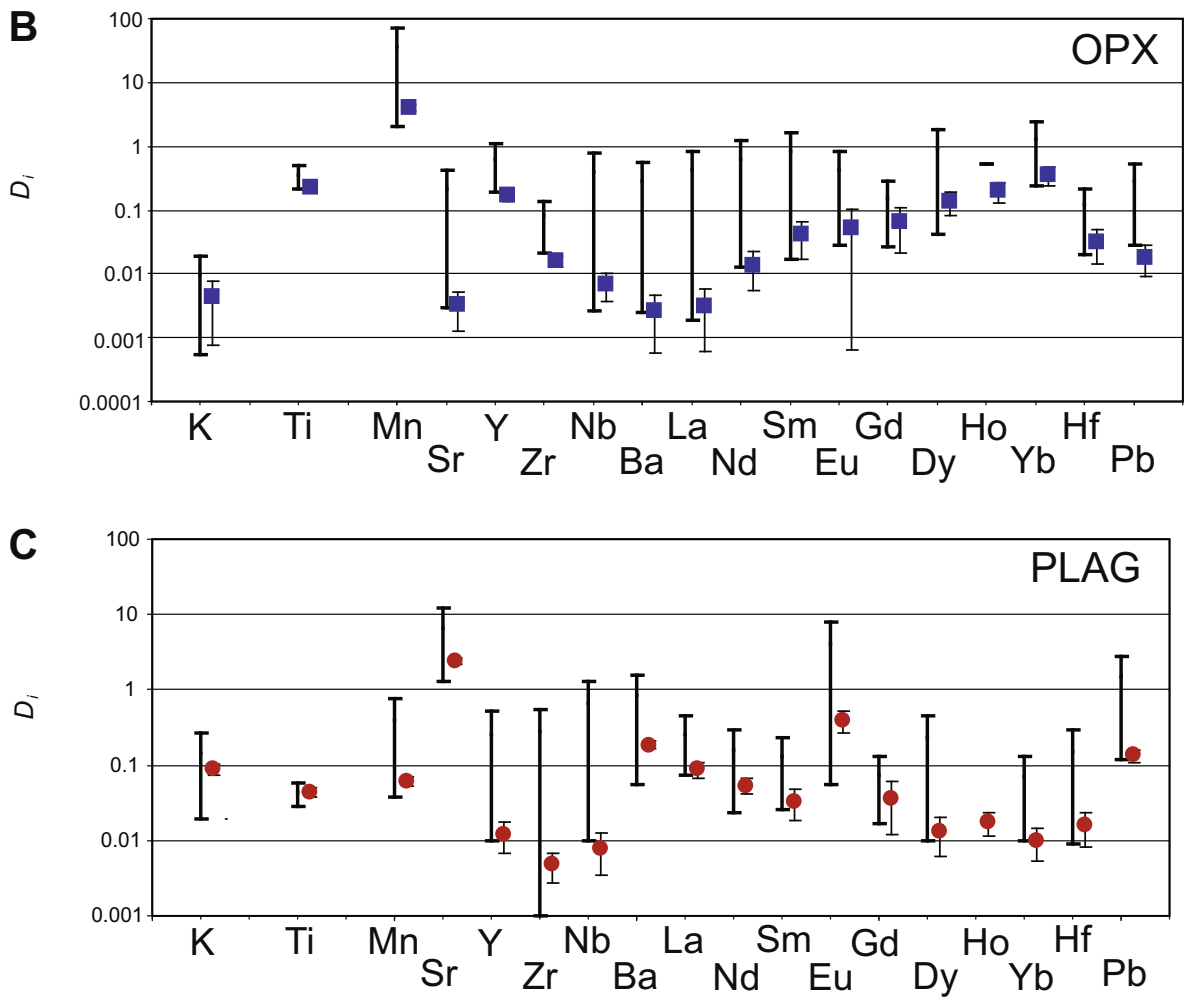

Fig. 7. Partition coefficients $\left(D_{i}\right)$ for LILE, HFSE, and REE from this study calculated from data listed in Tables 1 and 2 compared to published values (Philpotts and Schnetzler, 1970; Schnetzler and Philpotts, 1970; Ewart et al., 1973; Okamoto, 1979; Luhr and Carmichael, 1980; Green and Pearson, 1983; Fujimaki et al., 1984; Nash and Crecraft, 1985; Bacon and Druitt, 1988; Dunn and Sen, 1994; Ewart and Griffin, 1994; Forsythe et al., 1994). The symbols represent the average partition coefficient determined in this study, and the vertical line through the symbol represents the $2 \sigma$ standard deviation. The bold vertical line to the left of data from this study represents the complete range of partition coefficients reported in the literature. 
is trapped as a melt inclusion, incompatible elements would appear to be more compatible than they actually are, while compatible elements would appear to be less compatible than they would be without the presence of a boundary layer. If MIs in only one host phase are examined, it is difficult, if not impossible, to infer whether boundary layer processes have affected MI compositions. However, if two or more minerals are co-precipitating from the same melt, as is the case in this study, modifications to the melt inclusion composition by boundary layer processes can be recognized based on the compositions of melt inclusions contained in two or more hosts with different partitioning behavior for the same trace element. If boundary layers affected the MI compositions in this study, concentrations of elements that are compatible in one mineral and incompatible in another mineral should be significantly different in $\mathrm{MI}$ in the two different minerals. For example, $\mathrm{Sr}$ is compatible in plagioclase and incompatible in pyroxenes. If MI compositions were affected by the development of a boundary layer, the plagioclase-hosted MI should be depleted in Sr compared to pyroxene-hosted MI. Abundances for $\mathrm{Sr}$ (and all other measured elements) are similar in $\mathrm{MI}$ in all host phases (Table 2 and Fig. 6), suggesting that boundary layer processes did not affect the compositions of MIs in this study. Boundary layer processes should also have a larger relative effect on compositions of small inclusions compared to larger inclusions (assuming that the MI "size" reflects the thickness of the melt layer that is trapped to form the MI) and several workers have suggested that boundary layer effects only become important for inclusions smaller than $25 \mu \mathrm{m}$ (Anderson, 1974; Lowenstern, 1995; Lu et al., 1995). Recent work by Fedele et al. (2008) failed to identify any compositional variations that could be related to boundary layer processes for MI as small as $10 \mu \mathrm{m}$ in quartz and olivine. The melt inclusions studied here were all larger than $15 \mu \mathrm{m}$, and even the smallest inclusions analyzed did not show an enrichment in incompatible elements, or depletion in compatible elements, compared to the largest inclusions studied.

\subsection{Comparison of results of this study with previously published data}

Table 5 summarizes the currently available partition coefficients for orthopyroxene, clinopyroxene, and plagioclase in andesitic to rhyodacitic melts, and includes the $\mathrm{SiO}_{2}$ content, temperature, pressure, $\mathrm{H}_{2} \mathrm{O}$ content of the melt, mineral composition, $f \mathrm{O}_{2}$, and duration of the experiment if the information was reported as these variables are particularly important in controlling partitioning behavior (Wood and Blundy, 2003). Partitioning data from this study are generally consistent with the compatibility trends previously determined for these three different mineral phases. All measured trace elements except $\mathrm{Mn}$ are incompatible in orthopyroxene (Fig. 7B). The only element among those measured in this study that is compatible in plagioclase is $\mathrm{Sr}$ (Fig. 7C). The relatively high compatibility for Eu with respect to other REE in plagioclase reflects the reduction of $\mathrm{Eu}^{3+}$ to $\mathrm{Eu}^{2+}$, with the divalent cation being nearly as compatible in plagioclase as $\mathrm{Sr}$ (Aigner-Torres et al., 2007). Some transition metal elements (Sc, V, and $\mathrm{Mn})$ are compatible in clinopyroxene, and Y, the MREE, HREE, and Ti are only slightly incompatible (Fig. 7A). Most of the calculated partition coefficients from this study are within the wide range of published values but fall at the lower end of the range of the published values. The observation that partition coefficients determined in this study consistently lie at the lower end of the range in $D_{i}$ reported in the literature may be explained in several ways.

Most of the older published partition coefficient data for intermediate to silicic volcanic rocks is based on chemical analysis of glass and mineral separates using bulk analytical techniques (Philpotts and Schnetzler, 1970; Schnetzler and Philpotts, 1970; Ewart et al., 1973; Okamoto, 1979; Luhr and Carmichael, 1980; Fujimaki et al., 1984; Nash and Crecraft, 1985; Bacon and Druitt, 1988). The precision of partition coefficient data obtained using these bulk sampling techniques is poor because complete separation of phenocrysts from the matrix is not possible using mechan-

Table 5

Physical and chemical conditions of published partitioning studies.

\begin{tabular}{|c|c|c|c|c|c|c|}
\hline Reference & $\mathrm{SiO}_{2}\left(\mathrm{wt}^{0} \%\right)$ & $T\left({ }^{\circ} \mathrm{C}\right)$ & $P(\mathrm{~kb})$ & $\mathrm{H}_{2} \mathrm{O}(\mathrm{wt} \%)$ & Mineral comp. (OPX, CPX, Plag) & $f \mathrm{O}_{2}$, time \\
\hline Bacon and Druitt (1988) ${ }^{\mathrm{a}}$ & $63.6-72.2$ & $880-950$ & NR & $0.4-6.0$ & $\mathrm{En}_{66-81}, \mathrm{En}_{43-49} \mathrm{Wo}_{42-44}, \mathrm{An}_{52-84}$ & $\begin{array}{l}\log f \mathrm{O}_{2}=-10.5 \\
\text { to }-11.3\end{array}$ \\
\hline Dunn and Sen (1994) & 59.5 & $1100-1140$ & 1 & NR & $\mathrm{En}_{63-70}, \mathrm{An}_{54-68}$ & $\log f \mathrm{O}_{2}=\mathrm{QFM}$ \\
\hline Ewart et al. (1973) & $55-69$ & $1050-1250$ & $<2$ & $0.1-0.9$ & $\mathrm{En}_{50-71}, \mathrm{En}_{36-42} \mathrm{Wo}_{36-40}, \mathrm{An}_{80-85}$ & \\
\hline Ewart and Griffin (1994) & $68.5-75.8$ & NR & NR & NR & NR & \\
\hline Forsythe et al. (1994) & $62.3-64.9$ & $1072-1100$ & 0.001 & NR & $\mathrm{En}_{29-47} \mathrm{Wo}_{37-48}$ & $\log f \mathrm{O}_{2}=\mathrm{QFM}$ \\
\hline Fujimaki et al. (1984) & $55.0-70.8$ & NR & NR & $0.5-3.5$ & $\mathrm{En}_{52-66}, \mathrm{En}_{35-45} \mathrm{Wo}_{37-41}, \mathrm{An}_{40-82}$ & \\
\hline Green and Pearson (1983) & $59.4-62.5$ & $900-1050$ & $7.5-20$ & $2.0-5.0$ & NR & time $=6-24 \mathrm{~h}$ \\
\hline Luhr and Carmichael (1980) & $56.5-61.1$ & $940-1060$ & $0.7-1.0$ & $0.8-3.6$ & $\mathrm{En}_{68-79}, \mathrm{En}_{42-50} \mathrm{Wo}_{40-42}, \mathrm{An}_{30-85}$ & $\begin{array}{l}\log f \mathrm{O}_{2}=-7.8 \\
\text { to }-8.3\end{array}$ \\
\hline Nash and Crecraft (1985) & $70.9-75.0$ & $775-880$ & NR & $0.2-0.6$ & $\mathrm{An}_{34-42}$ & $\log f \mathrm{O}_{2}=-12.8$ \\
\hline Nagasawa and Schnetzler (1971) & NR & NR & NR & NR & NR & \\
\hline Okamoto (1979) & $58.5-73.1$ & NR & NR & NR & $\mathrm{An}_{60-62}$ & \\
\hline Philpotts and Schnetzler (1970) & NR & NR & NR & NR & NR & \\
\hline Schnetzler and Philpotts (1970) & NR & NR & NR & NR & NR & \\
\hline Zajacz and Halter (2007) & $56.6-57.3$ & NR & NR & NR & $\mathrm{An}_{77-87}$ & \\
\hline
\end{tabular}

\footnotetext{
a Temperature, mineral compositions, and $f \mathrm{O}_{2}$ estimates derived from the companion paper by Druitt and Bacon $(1990)$. NR $=$ not reported.
} 
ical (crushing) techniques to separate glass from crystals. An additional limitation of the phenocryst/matrix technique is that only the outermost portion of the phenocryst can be assumed to be in equilibrium with the surrounding melt phase and, if the crystal is zoned, the trace element concentration of interior portions of the crystal may be different than that of the outer portion, introducing errors into the estimated partition coefficient (Albarede and Bottinga, 1972). Perhaps the most significant shortcoming of the phenocryst-matrix technique is the likely presence of included accessory phases within the phenocryst (Michael, 1988; Sisson, 1991). Allanite, monazite, zircon, apatite, xenotime, sphene, ilmenite, and alkali feldspar are repositories of numerous elements of geochemical interest (e.g., REEs, Y, Hf, Zr, Th, and U). These phases, when present as inclusions, result in values for the incompatible trace element content of the phenocryst phase that are higher than the actual values (Jain et al., 2001; Hanchar and van Westrenen, 2007) and predict erroneously high $D_{i}$ values for incompatible elements. Thomas et al. (2002) suggested this process to explain differences between published $D_{i}$ and those obtained in their study to determine mineral-melt partition coefficients for zircon using the MIM technique. Modern analytical techniques with excellent spatial resolution allow inclusions to be avoided during analysis and thus eliminate this problem, but the majority of data in the literature for intermediate-felsic composition magmas are from earlier studies that did not have access to modern in situ microanalytical techniques.

Early experimental studies to investigate trace element partitioning often involved compositions with trace element concentrations significantly higher than natural levels to facilitate analysis using EPMA, instrumental neutron activation analysis, or thermal ionization mass spectrometry (Nagasawa, 1970; Fujimaki, 1986). These unnaturally elevated trace element concentrations raise questions about the applicability of Henry's Law behavior to interpret the experimental results (Drake and Holloway, 1978). Today, it is not necessary to use unnaturally elevated trace element concentrations in experimental studies owing to the availability of microanalytical techniques such as SIMS, LAICPMS, PIXE, and synchrotron X-ray fluorescence (SXRF) that offer good spatial resolution, ppb to $\mathrm{ppm}$ detection limits and high precision and accuracy. Questions remain, however, concerning the results from studies that used compositions with trace element abundances several orders of magnitude above natural abundances (Forsythe et al., 1994). Bindeman and Davis (2000) reported that partition coefficients determined experimentally using REEand Y-enriched concentrations may be $30-100 \%$ higher than partition coefficients derived from samples that had natural abundances of these elements. Another possible source of error in experimental studies is related to the rapid crystal growth rates that are often used. Rapid growth rates can produce zoned crystals (Bottinga et al., 1966; Kouchi et al., 1983; Tsuchiyama, 1985; Watson and Liang, 1995; Watson, 1996) and non-equilibrium distribution of trace elements between phases (Albarede and Bottinga, 1972; Henderson and Williams, 1979; Tsuchiyama, 1985).
Recent phenocryst-matrix studies have utilized PIXE (Ewart and Griffin, 1994) and SIMS (Dunn and Sen, 1994; Sano et al., 2002) to measure partition coefficients. These techniques allow foreign mineral inclusions and MIs to be avoided during the host analysis. Combined with imaging techniques, these microanalytical techniques provide a means to recognize and quantify compositional zonation within phenocrysts. However, if the glass surrounding the crystal does not represent the melt that the outermost portion of the crystal precipitated from, even these microanalytical techniques will produce incorrect partition coefficients. Proving chemical and textural equilibrium between phenocrysts and the immediately surrounding matrix glass in a volcanic rock is often difficult, if not impossible. Use of the MIM technique with glassy MIs represents a significant improvement in our ability to determine trace element partitioning behavior because there is no ambiguity concerning the temporal relationship between the melt and crystal, and analyses that include only melt (glass) or crystal in the analytical volume are easily obtained using LA-ICPMS or other microanalytical techniques.

Differences in partition coefficients observed when comparing data from different studies could be the result of differences in temperature, pressure, $\mathrm{H}_{2} \mathrm{O}$ content of the melt, $\mathrm{fO}_{2}$, or melt or host chemistry (Table 5). Previous studies (as summarized by Wood and Blundy, 2003) have shown that these factors can significantly affect partitioning behavior. Lowering the temperature will typically increase $D$ for most elements because it raises $\Delta S_{f}$ for the substitution of the trace element into the crystal structure (Wood and Blundy, 2002). This effect has been observed in earlier studies (Lindstrom and Weill, 1978; Ray et al., 1983; AignerTorres et al., 2007). The effect of pressure has not been studied in detail for crustal conditions. However, Green and Pearson (1983) found that increasing the pressure from 7.5 to $20 \mathrm{kbar}$ resulted in a small increase in $D$ for REE in clinopyroxene. Increasing the pressure can change the interatomic distance by up to $0.05 \AA$ for pressures up to $50 \mathrm{kbar}$ (Cameron and Papike, 1980). However, it is difficult to separate the effects of pressure from clinopyroxene mineral chemistry because tetrahedral $\mathrm{Al}$ content is strongly dependent upon pressure (Colson and Gust, 1989). Addition of $\mathrm{H}_{2} \mathrm{O}$ to an anhydrous melt lowers the $D$ because it reduces the activity of all trace components in the melt (Wood and Blundy, 2002) and decreases the $\Delta G$ of melting of dissolved trace elements (Green et al., 2000). However, Adam and Green (1994) found little difference in $D_{R E E}$ for clinopyroxenes in equilibrium with basanite melts containing 2.0 and $5.0 \mathrm{wt} \% \mathrm{H}_{2} \mathrm{O}$, respectively. An additional factor affecting partitioning behavior is the chemical composition of the mineral. Previous studies have shown that many trace elements are strongly affected by either the wollastonite or Ca-Tschermak content (Jones and McKay, 1992; Gaetani and Grove, 1995), or the tetrahedral Al content (LaTourrette and Burnett, 1992; Beattie, 1993; Hauri et al., 1994; McKay et al., 1994; Lundstrom et al., 1998; Francis and Minarik, 2008) of clinopyroxene. Similarly, partitioning of $\mathrm{Sr}$ and $\mathrm{Ba}$ in plagioclase feldspar is strongly 
Table 6

Comparison of mean partition coefficients from this study to four recent studies with similar magma compositions.

\begin{tabular}{|c|c|c|c|c|c|}
\hline & $\mathrm{CPX}^{\mathrm{a}}$ & $\mathrm{CPX}^{\mathrm{c}}$ & $\mathrm{CPX}^{\mathrm{c}}$ & $\mathrm{CPX}^{\mathrm{d}}$ & $\mathrm{CPX}^{\mathrm{e}}$ \\
\hline $\mathrm{Sc}$ & 3.306 & & & & 4.11 \\
\hline $\mathrm{Ti}$ & 0.412 & & & $0.34-0.89$ & 0.481 \\
\hline V & 1.532 & & & & 1.14 \\
\hline $\mathrm{Mn}$ & 2.877 & 4.5 & 6.1 & & 1.25 \\
\hline $\mathrm{Sr}$ & 0.101 & 0.075 & 0.2 & & 0.065 \\
\hline $\mathrm{Y}$ & 0.949 & 0.28 & 2.7 & & 0.698 \\
\hline $\mathrm{Zr}$ & 0.097 & 2.4 & 0.17 & $0.096-0.291$ & 0.105 \\
\hline $\mathrm{Nb}$ & 0.008 & $<0.87$ & $<1.0$ & $0.004-0.02$ & 0.021 \\
\hline $\mathrm{Ba}$ & 0.001 & 0.33 & 0.084 & & 0.0005 \\
\hline $\mathrm{La}$ & 0.082 & & & & 0.067 \\
\hline $\mathrm{Nd}$ & 0.380 & & & & 0.285 \\
\hline Sm & 0.610 & & & & 0.502 \\
\hline $\mathrm{Eu}$ & 0.626 & & & & 0.6 \\
\hline $\mathrm{Gd}$ & 0.907 & & & & 0.685 \\
\hline Dy & 0.926 & & & & \\
\hline Но & 1.009 & & & & 0.681 \\
\hline $\mathrm{Yb}$ & 0.973 & & & & 0.625 \\
\hline $\mathrm{Hf}$ & 0.171 & & & & 0.213 \\
\hline $\mathrm{Pb}$ & 0.012 & 0.11 & $<0.63$ & & 0.043 \\
\hline
\end{tabular}

\begin{tabular}{|c|c|c|c|c|}
\hline & $\mathrm{OPX}^{\mathrm{a}}$ & $\mathrm{OPX}^{\mathrm{b}}$ & $\mathrm{OPX}^{\mathrm{c}}$ & $\mathrm{OPX}^{\mathrm{c}}$ \\
\hline $\mathrm{Ti}$ & 0.228 & & & \\
\hline $\mathrm{Mn}$ & 4.055 & & 7.3 & $13.6-71.3$ \\
\hline $\mathrm{Sr}$ & 0.003 & $0.003-0.007$ & 0.13 & $0.068-0.18$ \\
\hline $\mathrm{Y}$ & 0.169 & $0.19-0.54$ & 0.46 & $0.44-1.07$ \\
\hline $\mathrm{Zr}$ & 0.016 & $0.021-0.04$ & 0.13 & $0.075-0.086$ \\
\hline $\mathrm{Nb}$ & 0.007 & 0.0027 & $<0.78$ & $0.54-0.73$ \\
\hline $\mathrm{Ba}$ & 0.003 & & 0.13 & $0.063-0.084$ \\
\hline $\mathrm{La}$ & 0.003 & $0.002-0.0023$ & & \\
\hline $\mathrm{Nd}$ & 0.014 & $0.013-0.027$ & & \\
\hline $\mathrm{Sm}$ & 0.041 & $0.063-0.089$ & & \\
\hline $\mathrm{Eu}$ & 0.052 & $0.059-0.086$ & & \\
\hline $\mathrm{Gd}$ & 0.064 & $0.069-0.24$ & & \\
\hline Dy & 0.138 & $0.15-0.4$ & & \\
\hline Ho & 0.199 & 0.52 & & \\
\hline $\mathrm{Yb}$ & 0.350 & $0.39-0.92$ & & \\
\hline $\mathrm{Hf}$ & 0.032 & & & \\
\hline $\mathrm{Pb}$ & 0.018 & 0.29 & $<0.52$ & $0.028-0.54$ \\
\hline
\end{tabular}

\begin{tabular}{|c|c|c|c|c|c|c|}
\hline & $\mathrm{PLAG}^{\mathrm{a}}$ & $\mathrm{PLAG}^{\mathrm{b}}$ & $\mathrm{PLAG}^{\mathrm{c}}$ & $\mathrm{PLAG}^{\mathrm{c}}$ & $\mathrm{PLAG}^{\mathrm{c}}$ & PLAG $^{\mathrm{e}}$ \\
\hline $\mathrm{Ti}$ & 0.043 & $0.04-0.057$ & & & & 0.029 \\
\hline $\mathrm{Mn}$ & 0.060 & & $<0.038$ & 0.17 & $<0.19$ & 0.042 \\
\hline $\mathrm{Sr}$ & 2.422 & $2.7-3.5$ & 5.28 & 10.7 & $7.6-7.8$ & 1.71 \\
\hline $\mathrm{Y}$ & 0.012 & 0.01 & $<0.066$ & 0.51 & $0.083-0.18$ & 0.11 \\
\hline $\mathrm{Zr}$ & 0.005 & 0.0051 & 0.15 & 0.55 & $0.10-0.18$ & 0.0051 \\
\hline $\mathrm{Nb}$ & 0.008 & $0.01-0.033$ & $<1.3$ & & $0.31-0.41$ & \\
\hline $\mathrm{Ba}$ & 0.186 & $0.38-0.55$ & 0.56 & 1.05 & $0.28-0.33$ & 0.143 \\
\hline $\mathrm{La}$ & 0.088 & $0.082-0.14$ & & & & 0.072 \\
\hline $\mathrm{Nd}$ & 0.054 & $0.045-0.069$ & & & & 0.043 \\
\hline $\mathrm{Sm}$ & 0.033 & $0.033-0.052$ & & & & 0.039 \\
\hline $\mathrm{Eu}$ & 0.397 & $0.55-0.79$ & & & & 0.258 \\
\hline $\mathrm{Gd}$ & 0.037 & $0.034-0.044$ & & & & 0.038 \\
\hline Dy & 0.013 & $0.025-0.034$ & & & & \\
\hline Ho & 0.017 & & & & & \\
\hline $\mathrm{Yb}$ & 0.010 & $0.012-0.014$ & & & & \\
\hline $\mathrm{Hf}$ & 0.016 & & & & & \\
\hline $\mathrm{Pb}$ & 0.134 & 1.07 & 2.8 & 1.3 & $0.35-0.84$ & 0.117 \\
\hline
\end{tabular}

${ }^{a}$ Results from this study.

b Dunn and Sen (1994); melt composition reported in Table 5.

${ }^{\text {c }}$ Ewart and Griffin (1994); melt composition reported in Table 5.

${ }^{d}$ Forsythe et al. (1994); melt composition reported in Table 5.

${ }^{\mathrm{e}}$ Zajacz and Halter (2007); melt composition reported in Table 5. 
dependent upon the anorthite content because albite is more elastic than anorthite (Blundy and Wood, 1992).

We have compared our results to recent studies of partitioning that utilized microanalytical techniques to analyze glass and minerals (Dunn and Sen, 1994; Ewart and Griffin, 1994; Forsythe et al., 1994), and which involved minerals and/or melt compositions similar to those in this study (Table 6 and Fig. 8). The mineral compositions and temperatures in the study of Dunn and Sen (1994) are similar to those of the present study; however, the $\mathrm{SiO}_{2}$ content of the melt in the study of Dunn and Sen (1994) (59.5 wt\%; Table 5) was slightly lower than that of the melt in this study $(\approx 65 \mathrm{wt} \%$; Table 2$)$. Melts studied by Forsythe et al. (1994) have $\mathrm{SiO}_{2}$ contents $(\approx 62-65 \mathrm{wt} \%$; Table 5) sim- ilar to the melts in this study, but the clinopyroxene composition is Fe- and Al-enriched (Table 5) compared to CPX from this study. The study of Ewart and Griffin (1994) included a wider range of melt composition, from andesite to low-Si rhyolite, compared to the present study.

Forsythe et al. (1994) report data for $\mathrm{Ti}, \mathrm{Zr}$ and $\mathrm{Nb}$, and partition coefficients determined in this study overlap with the lower end of the range in values from their study (Fig. 8C). The higher values reported by Forsythe et al. (1994) are consistent with previous studies (Hart and Dunn, 1993; McKay et al., 1994; Lundstrom et al., 1998) which have shown that $\mathrm{D}_{\mathrm{HFSE}}$ are higher in clinopyroxenes with higher $\mathrm{Al}_{2} \mathrm{O}_{3}$ content, compared to those with lower $\mathrm{Al}_{2} \mathrm{O}_{3}$. The results of Forsythe et al. (1994) are also similar
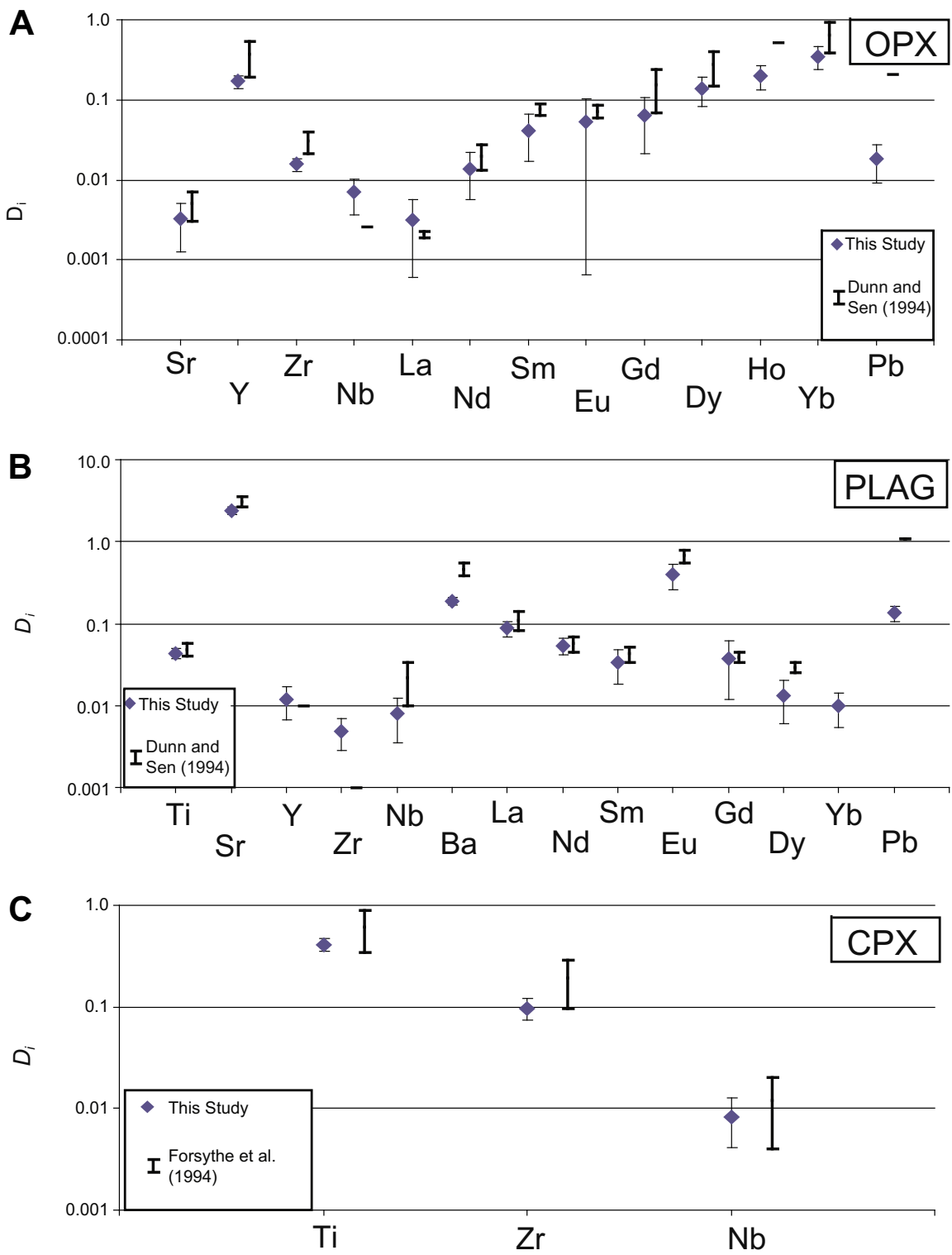

Fig. 8. Partition coefficients $\left(D_{i}\right)$ for LILE, HFSE, and REE from this study calculated from data listed in Tables 1 and 2 compared to published values from Dunn and Sen (1994) for orthopyroxene (A) and plagioclase (B) and from Forsythe et al. (1994) for clinopyroxene (C). The diamond-shaped point represents the average value from this study, and the thin vertical line centered on the average represents the $2 \sigma$ standard deviation. The bold horizontal line represents the range in values from the literature. 
to partition coefficients reported by Ewart and Griffin (1994) (Table 6), suggesting that even though the experiments of Forsythe et al. (1994) involved trace element-enriched compositions, trace element partitioning showed Henrian behavior. The results may reflect inherent differences in the substitution of HFSE compared to REE in the crystal lattice (Bindeman and Davis, 2000).

Partition coefficients for orthopyroxene determined in this study are generally lower than those from Dunn and Sen (1994) (Fig. 8A), with the exception of Nb and La. Partition coefficients reported by Dunn and Sen (1994) for plagioclase (Fig. 8B) are also generally higher than those from the present study, with the exception of $\mathrm{Y}$ and $\mathrm{Zr}$, although in many cases the values agree within $2 \sigma$. The consistently lower values for the partition coefficients for orthopyroxene and plagioclase would not have been predicted based on the lower $\mathrm{SiO}_{2}$ content of the melt in the study of Dunn and Sen (1994). Rather, the White Island samples should show higher partition coefficients for all incompatible elements because these elements are generally enriched in more silicic magmas. The effect of the differing $\mathrm{SiO}_{2}$ content may be offset by the more calcic composition of plagioclase at White Island, which averages $\mathrm{An}_{70}$ compared to $\mathrm{An}_{54-68}$ for plagioclase reported by Dunn and Sen (1994) The White Island orthopyroxene is also slightly more magnesian, averaging $\mathrm{En}_{71}$, compared to $\mathrm{En}_{63-70}$ reported by Dunn and Sen (1994).

A direct comparison with the results of Zajacz and Halter (2007) has not been attempted because the physical and chemical conditions pertaining to the two studies are very different. However, most of the $D_{R E E}$ from this study are consistently higher than those from Zajacz and Halter (2007), consistent with the lower $\mathrm{SiO}_{2}$ content of MI compared to the MI in this study. The lower $D_{\mathrm{Sr}}$ and $D_{\mathrm{Ba}}$ for

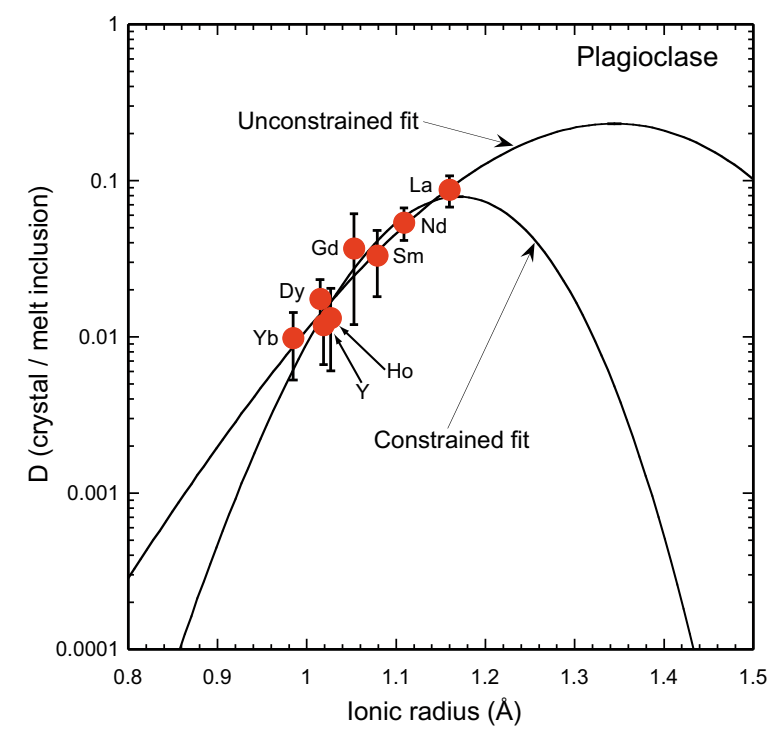

Fig. 9. Brice lattice strain model fits to $3+$ cation partitioning between plagioclase and dacitic melt at $1278 \mathrm{~K}$ and $0.1 \mathrm{GPa}$. The half parabola represents the fit when $r_{o}, D_{o}$, and $E$ are unconstrained and the full parabola represents the fit when Young's modulus is constrained at $200 \mathrm{GPa}$ (Wood and Blundy, 2003). Each data point includes $2 \sigma$ standard deviation. plagioclase reported by Zajacz and Halter (2007) may reflect the higher anorthite content of plagioclase in their samples.

The relationship between partitioning behavior for trace elements and ionic radii (Shannon, 1976) was first described by Onuma et al. (1968) and Jensen (1973). Wood and Blundy (1997) and Blundy and Wood (2003) presented a

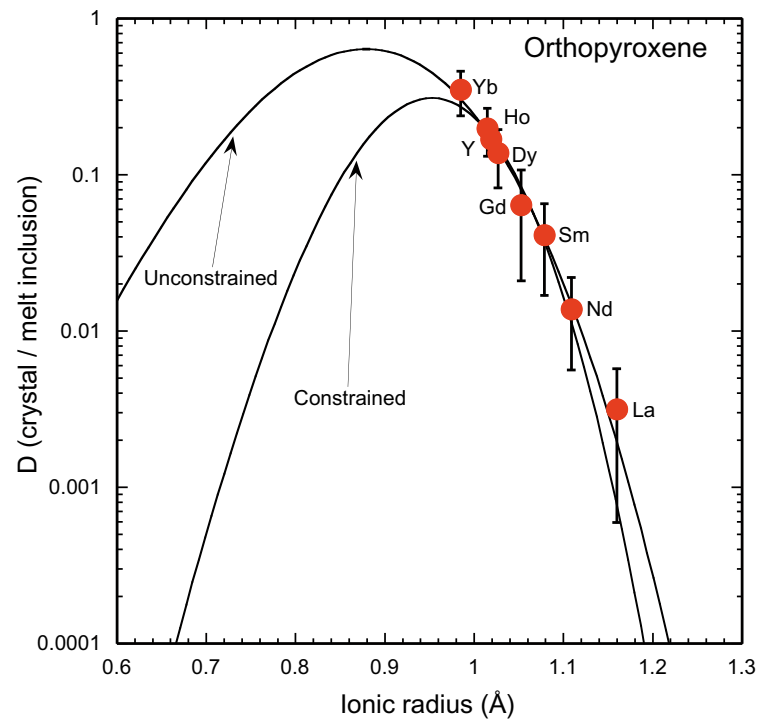

Fig. 10. Brice lattice strain model fits to $3+$ cation partitioning between orthopyroxene and dacitic melt at $1278 \mathrm{~K}$ and $0.1 \mathrm{GPa}$. The half parabola represents the fit when $r_{o}, D_{o}$, and $E$ are unconstrained and the full parabola represents the fit when Young's modulus is constrained at $360 \mathrm{GPa}$ (Wood and Blundy, 2003). Each data point includes $2 \sigma$ standard deviation.

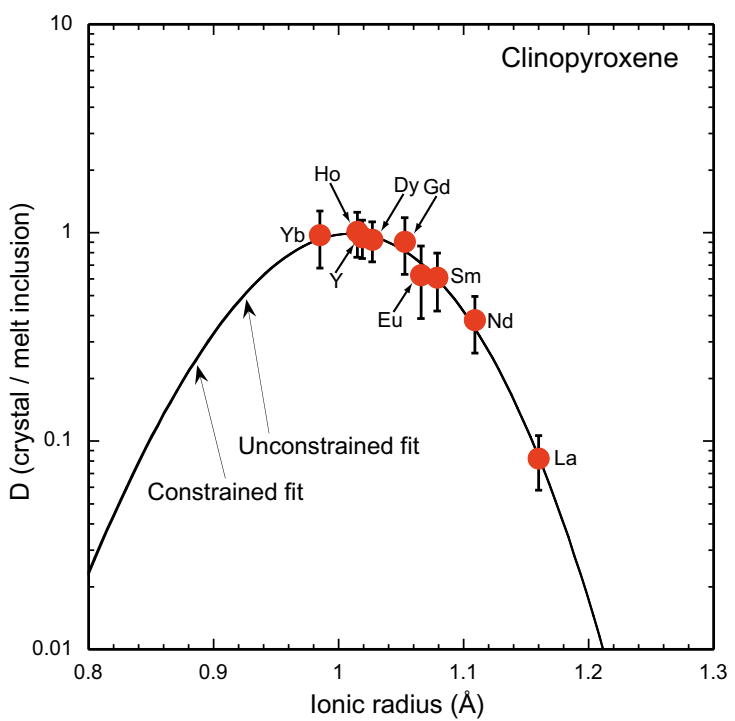

Fig. 11. Brice lattice strain model fits to $3+$ cation partitioning between clinopyroxene and dacitic melt at $1278 \mathrm{~K}$ and $0.1 \mathrm{GPa}$. The unconstrained and unconstrained fits both produce full parabolae that overlie each other. The constrained fit used a Young's modulus of $276 \mathrm{GPa}$ (Wood and Blundy, 2003). Each data point includes $2 \sigma$ standard deviation. 
quantitative model based on the modified Brice equation (Brice, 1975) that describes the relationship between trace element substitution in minerals and substitution-induced strain in the crystal structure (Lattice Strain Model LSM). The LSM relates the partition coefficient of an element $i\left(D_{i}\right)$, with a radius $r_{i}$, to the partition coefficient of an element $o\left(D_{o}\right)$ that has an ionic radius $r_{o}$ equal to the ideal size of the crystallographic site of interest:

$D_{i}=D_{0} \exp \frac{-4 \pi E N_{A}\left[\frac{r_{0}}{2}\left(r_{i}-r_{0}\right)^{2}+\frac{1}{3}\left(r_{i}-r_{0}\right)^{3}\right]}{R T}$

In Eq. (2), E is the Young's modulus of the site of interest, $N_{\mathrm{A}}$ is Avogadro's number, $R$ is the gas constant, and $T$ is temperature in $\mathrm{K}$. Two different approaches were used to compare the partitioning data from this study with the Bryce model described above. In the first case, $r_{o}, D_{o}$, and $E$ were completely unconstrained and their values were obtained by fitting a parabolic equation to the experimentally measured homovalent cation elements. In the second case, the Young's modulus, E, was constrained to a published value. Values of the Young's modulus used to fit the data were $200 \mathrm{GPa}$ for plagioclase (Wood and Blundy, 2003), $360 \mathrm{GPa}$ for orthopyroxene (Wood and Blundy, 2003), and $276 \mathrm{GPa}$ for clinopyroxene (Wood and Blundy, 2003). Initially a Young's modulus of $86 \mathrm{GPa}$ (Bedard, 2007) was selected for orthopyroxene, but this value resulted in unrealistic values for $r_{O}$ of $0.63 \AA$ and $D_{O}$ of 6.75. For this reason the value of $360 \mathrm{GPa}$ (Wood and Blundy, 2003) was chosen, resulting in a better fit to the data. In the unconstrained case, the fit only defines one limb of the parabola for plagioclase and orthopyroxene, whereas both limbs are defined for all three minerals with the constrained fit.

Partition coefficients predicted by the Brice lattice strain model using Eq. (2) for the $3+$ cations are plotted in Figs. 9-11 for plagioclase, orthopyroxene, and clinopyroxene, respectively, and the fitting parameters are listed in Table 7. These "Onuma plots" display the parabolic shape for $3+$ cations that is predicted by the lattice strain model. Clinopyroxene displays both limbs of the parabola and there is little difference between the unconstrained fit and the constrained fit. The two curves are indistinguishable and plot on top of one another (Fig. 11). However, because of the limited size range of cations analyzed here, $3+$ cations for orthopyroxene and plagioclase only define one limb of the parabola for the unconstrained fit (Figs. 9 and 10). The unconstrained model predicts incorrect values of $r_{o}$ and $D_{o}$ as a result of only having one limb of the parabola defined (Figs. 9 and 10). Wood and Blundy (2003) note that lattice strain parameters for $3+$ cations entering plagioclase are difficult to derive because $r^{3+}$ is clearly larger than $\mathrm{La}^{3+}$, meaning that one limb of the parabola is not well-defined. Previous workers have suggested that the apices of these parabolae lie at an ionic radius slightly larger than that for La in plagioclase (Aigner-Torres et al., 2007) and at approximately the ionic radius of $\mathrm{Lu}$ for orthopyroxene (Schwandt and McKay, 1998; Norman et al., 2005).

The Brice equation was not applied to the $2+$ cations in this study for several reasons. First, compared to the $3+$ cations, relatively few $2+$ cations were measured. Of these, $\mathrm{Pb}^{2+}$ deviates significantly from the predicted behavior because it is a non-spherical ion resulting from lone pairs of electrons, and Mn does not always fit the predicted model because of electronic effects (Wood and Blundy, 2003). Wood and Blundy (2003) also note that fitted $r_{o}$ values for $2+$ cations have higher uncertainties compared to ions with higher charges.

\section{SUMMARY}

The MIM technique described by Lu et al. (1992) and Sobolev et al. (1996) and further developed by Thomas et al. (2002, 2003) and Zajacz and Halter (2007) has been applied to determine partition coefficients for Sc, Ti, V, $\mathrm{Mn}, \mathrm{Sr}, \mathrm{Y}, \mathrm{Zr}, \mathrm{Nb}, \mathrm{Ba}, \mathrm{La}, \mathrm{Nd}, \mathrm{Sm}, \mathrm{Eu}, \mathrm{Gd}, \mathrm{Dy}, \mathrm{Ho}$, $\mathrm{Yb}$, Hf, and $\mathrm{Pb}$ between clinopyroxene, orthopyroxene, plagioclase, and dacitic melt. Samples from the 1988 eruption of White Island, New Zealand, contain clinopyroxene, orthopyroxene, and plagioclase that were all co-precipitating from the same melt that was trapped as MIs. Compositions of MIs do not vary with host phase, indicating that boundary layer and post-entrapment processes have not affected the MI compositions. All trace elements examined in this study except $\mathrm{Sr}$ are incompatible in plagioclase, and all measured trace elements are incompatible in orthopyroxene except for Mn. In clinopyroxene, Sc, V, and Mn are compatible, and Ti, Y, HREE, and the MREE are only slightly incompatible. Results from this study are consistent with published partition coefficients; however, our values typically lie at the lower end of the range of published values. These differences are thought to be due to either synthetic crystal growth rates that are too fast and/or unnaturally elevated trace element concentrations in the melt for experimental studies, or the presence of crystal zonation or mineral inclusions in natural phenocryst-matrix studies, or some combination of these factors. The partitioning data for $3+$ cations in clinopyroxene is consistent with the crystal lattice strain model derived by Wood and Blundy (1997) and Blundy and Wood (2003).

Table 7

Fitting parameters used in the lattice strain model for $3+$ cations.

\begin{tabular}{llll}
\hline Mineral & $r_{0}(\AA)$ & $D_{\text {o }}$ & $E(\mathrm{GPa})$ \\
\hline CPX (constrained) & $1.010 \pm 0.009$ & $0.986 \pm 0.114$ & 276 \\
CPX (unconstrained) & $1.009 \pm 0.025$ & $0.987 \pm 0.123$ & $275.0 \pm 97.2$ \\
OPX (constrained) & $0.953 \pm 0.019$ & $0.309 \pm 0.115$ & 360 \\
OPX (unconstrained) & $0.879 \pm 0.198$ & $0.636 \pm 1.37$ & $193.0 \pm 216.3$ \\
Plag (constrained) & $1.169 \pm 0.014$ & $0.079 \pm 0.017$ & 200 \\
Plag (unconstrained) & $1.344 \pm 0.484$ & $0.231 \pm 0.811$ & $64.8 \pm 119.8$ \\
\hline
\end{tabular}




\section{ACKNOWLEDGEMENTS}

The authors thank C. Loehn and R. Tracy for assistance with EPMA analyses of the samples, and S. Becker, C. Cannatelli, and A. Fall for critical comments on the manuscript. Detailed comments on an earlier version of this manuscript by Zoltan Zajacz, Wim van Westrenen, Peter Ulmer and an anonymous reviewer are appreciated. We thank C. Peter Wood and Stuart Simmons for providing the White Island samples used in this study. Funding was provided by the Cunningham Fellowship from Virginia Tech to M.J.S. and NSF Grants EAR-0337094 and EAR-0322119 to R.J.B.

\section{REFERENCES}

Adam J. and Green T. H. (1994) The effects of pressure and temperature on the partitioning of $\mathrm{Ti}, \mathrm{Sr}$, and $\mathrm{REE}$ between amphibole, clinopyroxene and basanitic melts. Chem. Geol. 117, 219-233.

Adam J., Green T. H. and Sie S. H. (1993) Proton microprobe determined partitioning of $\mathrm{Rb}, \mathrm{Sr}, \mathrm{Ba}, \mathrm{Y}, \mathrm{Zr}, \mathrm{Nb}$ and $\mathrm{Ta}$ between experimentally produced amphiboles and silicate melts with variable F content. Chem. Geol. 109, 29-49.

Aigner-Torres M., Blundy J., Ulmer P. and Pettke T. (2007) Laser ablation ICPMS study of trace element partitioning between plagioclase and basaltic melts: an experimental approach. Contrib. Mineral. Petrol. 153, 647-667.

Albarede F. and Bottinga Y. (1972) Kinetic disequilibrium in trace element partitioning between phenocrysts and host lava. Geochim. Cosmochim. Acta 36, 141-156.

Anderson A. T. J. (1974) Evidence for a picritic, volatile-rich magma beneath Mt. Shasta, California. J. Petrol. 15, 243267.

Asimow P. D. and Ghiorso M. S. (1998) Algorithmic modifications extending MELTS to calculate subsolidus phase relations. $\mathrm{Am}$. Mineral. 83, 1127-1131.

Ayers J.C. and Luo Y. (2008) Use of newly measured zircon/melt partition coefficients to identify the source of Hadean zircons. Goldschmidt Conference Abstracts 2008. Geochim. Cosmochim. Acta 72, A39 (Suppl. 1).

Bacon C. R. (1989) Crystallization of accessory phases in magma by local saturation adjacent to phenocrysts. Geochim. Cosmochim. Acta 53, 1055-1066.

Bacon C. R. (1990) Calc-alkaline, shoshonitic, and primitive tholeiitic lavas from monogenetic volcanoes near Crater Lake, Oregon. J. Petrol. 31, 135-166.

Bacon C. R. and Druitt T. H. (1988) Compositional evolution of the zoned calcalkaline magma chamber of Mount Mazama, Crater Lake, Oregon. Contrib. Mineral. Petrol. 98, 224-256.

Baker D. R. (2008) The fidelity of melt inclusions as records of melt composition. Contrib. Mineral. Petrol. 156, 377-395.

Beattie P. (1993) The generation of uranium series disequilibria by partial melting of spinel peridotite: constraints from partitioning studies. Earth Planet. Sci. Lett. 117, 379-391.

Beattie P., Drake M., Jones J., Leeman W., Longhi J., McKay G., Nielsen R., Palme H., Shaw D., Takahashi E. and Watson E. B. (1993) Terminology for trace-element partitioning. Geochim. Cosmochim. Acta 57, 1605-1606.

Bedard J. H. (2007) Trace element partitioning between silicate melts and orthopyroxene: parameterizations of $D$ variations. Chem. Geol. 244, 263-303.

Bindeman I. N. and Davis A. M. (2000) Trace element partitioning between plagioclase and melt: investigation of dopant influence on partition behavior. Geochim. Cosmochim. Acta 64, 28632878.
Blundy J. D. and Wood B. J. (1992) Partitioning of strontium between plagioclase and melt: reply to the comment by S. A. Morse. Geochim. Cosmochim. Acta 56, 1739-1741.

Blundy J. D. and Wood B. J. (2003) Partitioning of trace elements between crystals and melt. Earth Planet. Sci. Lett. 210, 383-397.

Bodnar R. J. and Student J. J. (2006) Melt inclusions in plutonic rocks: petrography and microthermometry. In Melt Inclusions in Plutonic Rocks (ed. J. D. Webster). Mineralogical Association of Canada.

Bottinga Y., Kudo A. and Weill D. (1966) Some observations on oscillatory zoning and crystallization of magmatic plagioclase. Am. Mineral. 51, 792-806.

Brice J. C. (1975) Some thermodynamic aspects of the growth of strained crystals. J. Cryst. Growth 28, 249-253.

Cameron M. and Papike J. J. (1980) Crystal chemistry of silicate pyroxenes. In Pyroxenes (ed. C. T. Prewitt). Mineralogical Society of America, Washington, DC.

Clark R. H. and Cole J. W. (1989) Volcanic monitoring and surveillance at White Island before the 1976-1982 eruption sequence. In The 1976-1982 eruption sequence at White Island volcano (Whakaari), Bay of Plenty, New Zealand (eds. B. F. Houghton and I. A. Nairn). New Zealand Geological Survey, Lower Hutt, New Zealand.

Cole, J. W. and Nairn, I. A., 1975. Part 22: New Zealand. In Catalogue of the active volcanoes of the world including Solfatara fields (ed. International Association of Volcanology and Chemistry of the Earth's Interior). Naples, Italy.

Colson R. O. and Gust D. (1989) Effects of pressure on partitioning of trace element between low-Ca pyroxene and melt. Am. Mineral. 74, 31-36.

Danyushevsky L. V., Della-Pasqua F. N. and Sokolov S. (2000) Re-equilibration of melt inclusions trapped by magnesian olivine phenocrysts from subduction-related magmas: petrological implications. Contrib. Mineral. Petrol. 138, 68-83.

Danyushevsky L. V., McNeill A. W. and Sobolev A. V. (2002) Experimental and petrological studies of melt inclusions in phenocrysts from mantle-derived magmas: an overview of techniques, advantages and complications. Chem. Geol. 183, 524.

Drake M. J. and Holloway J. R. (1978) "Henry's Law" behavior of $\mathrm{Sm}$ in a natural plagioclase/melt system: importance of experimental procedure. Geochim. Cosmochim. Acta 42, 679-683.

Dunn T. and Sen C. (1994) Mineral/matrix partition coefficients for orthopyroxene, plagioclase, and olivine in basaltic to andesitic systems: a combined analytical and experimental study. Geochim. Cosmochim. Acta 58, 717-733.

Ewart A., Bryan W. B. and Gill J. B. (1973) Mineralogy and geochemistry of the younger volcanic islands of Tonga, S.W. Pacific. J. Petrol. 14, 429-465.

Ewart A. and Griffin W. L. (1994) Application of protonmicroprobe data to trace-element partitioning in volcanic rocks. Chem. Geol. 117, 251-284.

Fedele L., Cannatelli C., Bodnar R.J. and Severs M. (2008) Do boundary layers affect the compositions of melt inclusions? No. In Ninth Pan American Conference on Research on Fluid Inclusions, Program and Abstracts (ed. H. E. Belkin). p. 26.

Forsythe L. M., Nielsen R. L. and Fisk M. R. (1994) High-field strength element partitioning between pyroxene and basaltic to dacitic magmas. Chem. Geol. 117, 107-125.

Fowler S. J., Spera F. J., Bohrson W. A., Belkin H. E. and De Vivo B. (2007) Phase equilibria constraints on the chemical and physical evolution of the Campanian Ignimbrite. J. Petrol. 48, 459-493.

Francis D. and Minarik W. (2008) Aluminum-dependent trace element partitioning in clinopyroxene. Contrib. Mineral. Petrol. 156, 439-451. 
Fujimaki H. (1986) Partition coefficients of Hf, Zr, and REE between zircon, apatite, and liquid. Contrib. Mineral. Petrol. 94, 42-45.

Fujimaki H., Tatsumoto M. and Aoki K.-i. (1984) Partition coefficients of $\mathrm{Hf}, \mathrm{Zr}$, and REE between phenocrysts and groundmasses. J. Geophys. Res. 89, B662-672.

Gaetani G. A. and Grove T. L. (1995) Partitioning of rare earth elements between clinopyroxene and silicate melt: crystalchemical controls. Geochim. Cosmochim. Acta 59, 1951-1962.

Gaetani G. A. and Watson E. B. (2000) Open system behavior of olivine-hosted melt inclusions. Earth Planet. Sci. Lett. 183, 27-41.

Gast P. W. (1968) Trace element fractionation and origin of tholeiitic and alkaline magma types. Geochim. Cosmochim. Acta 32, 1057-1086.

Ghiorso M. S. and Sack R. O. (1995) Chemical mass transfer in magmatic processes. IV. A revised and internally consistent thermodynamic model for the interpolation and extrapolation of liquid-solid equilibria in magmatic systems at elevated temperatures and pressures. Contrib. Mineral. Petrol. 119, 197212.

Giggenbach W. F. and Glasby C. (1977) The influence of thermal activity on the trace metal distribution in marine sediments around White Island, New Zealand. NZ Dep Sci. Ind. Res. Bull. 218, 121-126.

Graham J. J. and Cole J. W. (1991) Petrogenesis of andesite and dacites of White Island volcano, Bay of Plenty, New Zealand, in the light of new geochemical and isotopic data. $N Z \mathrm{~J}$. Geol. Geophys. 34, 303-315.

Green, T. H., Blundy, J., Adam, J. and Yaxley, G. M., 2000. SIMS determination of trace element partition coefficients between garnet, clinopyroxene, and hydrous basaltic liquids at 27.5 GPa and $1080-1200^{\circ} \mathrm{C}$. Lithos 53, 165-187.

Green T. H. and Pearson N. J. (1983) Effect of pressure on rare earth element partition coefficients in common magmas. Nature 305, 414-416.

Halter W. E., Pettke T., Heinrich C. A. and Rothen-Rutishauser B. (2002) Major to trace element analysis of melt inclusions by laser ablation ICPMS: methods of quantification. Chem. Geol. 183, 63-86.

Hanchar, J. M. and van Westrenen, W., 2007. Rare earth element behavior in zircon-melt systems. Elements 3, 37-42.

Hart S. R. and Brooks C. (1974) Clinopyroxene-matrix partitioning of $\mathrm{K}, \mathrm{Rb}, \mathrm{Cs}, \mathrm{Sr}$ and Ba. Geochim. Cosmochim. Acta 38, 1799-1806.

Hart S. R. and Dunn T. (1993) Experimental cpx/melt partitioning of 24 trace elements. Contrib. Mineral. Petrol. 113, 1-8.

Hauri E. H., Wagner T. P. and Grove T. L. (1994) Experimental and natural partitioning of $\mathrm{Th}, \mathrm{U}, \mathrm{Pb}$ and other trace elements between garnet, clinopyroxene and basaltic melts. Chem. Geol. 117, 149-166.

Henderson P. and Williams C. T. (1979) Variation in trace element partition (crystal/magma) as a function of crystal growth rate. Phys. Chem. Earth 11, 191-198.

Hougton B. F. and Nairn I. A. (1991) The 1976-1982 Strombolian and phreatomagnatic eruptions of White Island, New Zealand: eruptive and depositional mechanisms at a "wet" volcano. Bull. Volcanol. 54, 25-49.

Irving A. J. and Frey F. A. (1984) Trace element abundances in megacrysts and their host basalts: constraints on partition coefficients and megacryst genesis. Geochim. Cosmochim. Acta 48, 1201-1221.

Isacks B., Oliver J. and Sykes L. R. (1968) Seismology and the new global tectonics. J. Geophys. Res. 73, 5585-5899.

Jain J. C., Neal C. R. and Hanchar J. M. (2001) Problems associated with the determination of rare earth elements of a "gem" quality zircon by inductively coupled plasma-mass spectrometry. Geostandards Newslett. 25, 229-237.
Jensen B. B. (1973) Patterns of trace element partitioning. Geochim. Cosmochim. Acta 37, 2227-2242.

Jones, J. H. and McKay, G. A., 1992. REE partitioning between pyroxen/liquid and garnet/liquid: parameterization using $D_{\mathrm{Ca}}$. Eos (Transactions of the American Geophysical Union) 73, 307.

Kouchi A., Sugawara Y., Kashima K. and Sinagawa I. (1983) Laboratory growth of sector zoned clinopyroxenes in the system $\mathrm{CaMgSi}_{2} \mathrm{O}_{6}-\mathrm{CaTiAl}_{2} \mathrm{O}_{6}$. Contrib. Mineral. Petrol. 83, 177-184.

LaTourrette T. Z. and Burnett D. S. (1992) Experimental determination of $\mathrm{U}$ and $\mathrm{Th}$ partitioning between clinopyroxene and natural and synthetic basaltic liquid. Earth Planet. Sci. Lett. 110, 227-244.

Lindstrom D. J. and Weill D. F. (1978) Partitioning of transition metals between diopside and coexisting silicate liquids: I. Nickel, cobalt, and manganese. Geochim. Cosmochim. Acta 42, 817-831.

Lowenstern J. B. (1995) Applications of silicate-melt inclusions to the study of magmatic volatiles. In Magmas, Fluid and Ore Deposits (ed. J. F. H. Thompson). Mineralogical Association of Canada.

Lu F., Anderson A. T. and Davis A. M. (1992) New and larger sanidine/melt partition coefficients for $\mathrm{Ba}$ and $\mathrm{Sr}$ as determined by ion microprobe analyses of melt inclusions and their sanidine host crystals. Geol. Soc. Am. Abstr. Programs 24, A44.

Lu F., Anderson A. T. and Davis A. M. (1995) Diffusional gradients at the crystal/melt interface and their effect on the composition of melt inclusions. J. Geol. 103, 591-597.

Luhr J. F. and Carmichael I. S. E. (1980) The Colima Volcanic Complex, Mexico: I. Post-caldera andesites from Volcan Colima. Contrib. Mineral. Petrol. 71, 343-372.

Lundstrom C. C., Shaw H. F., Ryerson F. J., Williams Q. and Gill J. B. (1998) Crystal chemical control of clinopyroxene-melt partitioning in the $\mathrm{Di}-\mathrm{Ab}-\mathrm{An}$ system: implications for elemental fractionations in the depleted mantle. Geochim. Cosmochim. Acta 62, 2849-2862.

McKay G. A., Le L., Wagstaff J. and Crozaz G. (1994) Experimental partitioning of rare earth elements and strontium: constraints on petrogenesis and redox conditions during crystallization of Antarctic angrite Lewis Cliff 86010. Geochim. Cosmochim. Acta 58, 2911-2919.

Michael P. J. (1988) Partition coefficients for rare earth elements in mafic minerals of high silica rhyolites: the importance of accessory mineral inclusions. Geochim. Cosmochim. Acta 52, 275-282.

Mutchler S. R., Fedele L. and Bodnar R. J. (2007) AMS a new software package for reduction of Laser Ablation ICPMS data. In ECROFI XIX (ed. L. Diamond). Berne, Switzerland.

Mutchler S. R., Fedele L. and Bodnar R. J. (2008) Analysis Management System (AMS) for reduction of laser ablation ICPMS data. In Laser-Ablation-ICPMS in the Earth Sciences: Current Practices and Outstanding Issues (ed. P. Sylvester). Mineralogical Association of Canada, Quebec.

Nagasawa H. (1970) Rare earth concentrations in zircons and apatites and their host dacites and granites. Earth Planet. Sci. Lett 9, 359-364.

Nagasawa H. and Schnetzler C. C. (1971) Partitioning of rare earth, alkali and alkaline earth elements between phenocrysts and acidic magma. Geochim. Cosmochim. Acta 35, 953-968.

Nash W. P. and Crecraft H. R. (1985) Partition coefficients for trace elements in silicic magmas. Geochim. Cosmochim. Acta 49, 2309-2322.

Norman M., Garcia M. O. and Pietruszka A. J. (2005) Traceelement distribution coefficients for pyroxenes, plagioclase, and olivine in evolved tholeiites from the 1955 eruption of Kilauea Volcano, Hawai'i, and petrogenesis of differentiated rift-zone lavas. Am. Mineral. 90, 888-899. 
Okamoto K. (1979) Geochemical study on magmatic differentiation of Asama Volcano, Central Japan. J. Geol. Soc. Japan 85, $525-535$.

Onuma N., Higuchi H., Wakita H. and Nagasawa H. (1968) Trace element partitioning between two pyroxenes and the host lava. Earth Planet. Sci. Lett. 5, 47-51.

Pearce J. A. and Cann J. R. (1973) Tectonic setting of basic volcanic rocks determined using trace element analyses. Earth Planet. Sci. Lett. 19, 290-300.

Philpotts J. A. and Schnetzler C. C. (1970) Phenocryst-matrix partition coefficients for $\mathrm{K}, \mathrm{Rb}, \mathrm{Sr}$ and $\mathrm{Ba}$, with applications to anorthosite and basalt genesis. Geochim. Cosmochim. Acta 34, 307-322.

Rapien M. H. (1998) Geochemical Evolution at White Island. Masters, Virginia Polytechnical Institute and State University, New Zealand.

Rapien M. H., Bodnar R. J., Simmons S. F., Szabo C. S., Wood C. P. and Sutton S. R. (2003) Melt inclusion study of the embryonic porphyry copper system at White Island, New Zealand. Soc. Econ. Geol. Special Publ. 10, 41-59.

Ray G. L., Shimizu N. and Hart S. R. (1983) An ion microprobe study of the partitioning of trace elements between clinopyroxene and liquid in the system diopside-albite-anorthite. Geochim. Cosmochim. Acta 47, 2131-2140.

Rollinson H. R. (1993) Using Geochemical Data: Evaluation, Presentation, Interpretation. Pearson Education Limited, Harlow, England.

Sano Y., Terada K. and Fukuoka T. (2002) High mass resolution ion microprobe analysis of rare earth elements in silicate glass, apatite and zircon: lack of matrix dependency. Chem. Geol. 184, $217-230$.

Schnetzler C. C. and Philpotts J. A. (1970) Partition coefficients of rare-earth elements between igneous matrix material and rockforming mineral phenocrysts - II. Geochim. Cosmochim. Acta 34, 331-340.

Schwandt C. S. and McKay G. A. (1998) Rare earth element partition coefficients from enstatite/melt synthesis experiments. Geochim. Cosmochim. Acta 62, 2845-2848.

Shannon R. D. (1976) Revised effective ionic radii and systematic studies of interatomic distances in halides and chalcogenides. Acta Crystallogr. A32, 751-767.

Shaw D. M. (2006) Trace Elements in Magmas: Theoretical Treatment. Cambridge University Press, Cambridge, UK.

Shimizu N. (1974) An experimental study of the partitioning of K, $\mathrm{Rb}, \mathrm{Cs}, \mathrm{Sr}$, and $\mathrm{Ba}$ between clinopyroxene and liquid at high pressures. Geochim. Cosmochim. Acta 38, 1789-1798.

Sisson, T. W., 1991. Pyroxene-high silica rhyolite trace element partition coefficients measured by ion microprobe. Geochim. Cosmochim. Acta 55.

Sobolev A. V., Migdisov A. A. and Portnyagin M. V. (1996) Incompatible element partitioning between clinopyroxenes and basaltic liquid revealed by study of melt inclusions in minerals from Troodos Lavas, Cyprus. Petrology 4, 307-317.

Student J. J. and Bodnar R. J. (1999) Synthetic fluid inclusions XIV: coexisting silicate melt and aqueous fluid inclusions in the haplogranite- $\mathrm{H}_{2} \mathrm{O}-\mathrm{NaCl}-\mathrm{KCl}$ system. J. Petrol. 40, 1509-1525.

Sun S. S. and McDonough W. F. (1989) Chemical and isotopic systematics of oceanic basalts: implications for mantle composition and processes. In Magmatism in the Ocean Basins (eds. A. D. Saunders and M. J. Norry). Blackwell Scientific Publications, Boston.
Thomas J. B. and Bodnar R. J. (2002) A technique for mounting and polishing melt inclusions in small $(>1 \mathrm{~mm})$ crystals. $A m$. Mineral. 87, 1505-1508.

Thomas J. B., Bodnar R. J., Shimizu N. and Chesner C. (2003) Melt Inclusions in Zircon. In Zircon (eds. J. M. Hanchar and P. W. O. Hoskins). Mineralogical Society of America, Washington, DC.

Thomas J. B., Bodnar R. J., Shimizu N. and Sinha A. K. (2002) Determination of zircon/melt trace element partition coefficients from SIMS analysis of melt inclusions in zircon. Geochim. Cosmochim. Acta 66, 2887-2901.

Thompson G. M. and Malpas J. (2000) Mineral/melt partition coefficients of oceanic alkali basalts determined on natural samples using laser ablation-inductively coupled plasma-mass spectrometry (LAM-ICP-MS). Mineral. Mag. 64, 85-94.

Tsuchiyama A. (1985) Crystallization kinetics in the system $\mathrm{CaMgSi}_{2} \mathrm{O}_{6}-\mathrm{CaAl}_{2} \mathrm{Si}_{2} \mathrm{O}_{8}$ : development of zoning and kinetics effects on element partitioning. Am. Mineral. 70, 474- 486.

Wardell L. J., Kyle P. R., Dunbar N. and Christenson B. (2001) White Island volcano, New Zealand: carbon dioxide and sulfur dioxide emission rates and melt inclusion studies. Chem. Geol. 177, 187-200.

Watson E. B. (1996) Dissolution, growth and survival of zircons during crustal fusion: kinetic principles, geologic models and implications for isotopic inheritance. Trans. R. Soc. Edinburgh Earth Sci. 87, 43-56.

Watson E. B. and Liang Y. (1995) A simple model for sector zoning in slowly grown crystals: implications for growth rate and lattice diffusion, with emphasis on accessory minerals in crustal rocks. Am. Mineral. 80, 1179-1187.

Wilson B. M. (1994) Igneous Petrogenesis. Chapman and Hall, London.

Wood B. J. and Blundy J. D. (1997) A predictive model for rare earth element partitioning between clinopyroxene and anhydrous silicate melt. Contrib. Mineral. Petrol. 129, 166-181.

Wood B. J. and Blundy J. D. (2002) The effect of $\mathrm{H}_{2} \mathrm{O}$ on crystalmelt partitioning of trace elements. Geochim. Cosmochim. Acta 66, 3647-3656.

Wood B. J. and Blundy J. D. (2003) Trace element partitioning under crustal and uppermost mantle conditions: the influences of ionic radius, cation charge, pressure, and temperature. In Mantle and Core (ed. R. W. Carlson). Elsevier.

Wood C. P. and Browne P. R. L. (1996) Chlorine-rich pyrometamorphic magma at White Island volcano, New Zealand. $J$. Volcanol. Geothermal Res. 72, 21-35.

Yang H., Kinzler J. K. and Grove T. L. (1996) Experiments and models of anhydrous, basaltic olivine-plagioclase-augite saturated melts from 0.001 to 10 kbar. Contrib. Mineral. Petrol. 124, $1-18$.

Zajacz Z. and Halter W. (2007) LA-ICPMS analyses of silicate melt inclusions in co-precipitated minerals: quantification, data analysis and mineral/melt partitioning. Geochim. Cosmochim. Acta 71, 1021-1040.

Zielinski R. A. and Frey F. A. (1970) Gough Island: evaluation of a fractional crystallization model. Contrib. Mineral. Petrol. 29, 242-254.

Zielinski R. A. and Frey F. A. (1974) An experimental study of a rare earth element in the system diopside/water. Geochim. Cosmochim. Acta 38, 545-565. 